\title{
AVRUPA İNSAN HAKLARI MAHKEMESİ KARARLARINDA MÜKELLEF HAKLARI: MÜLKIYYET HAKKI VE ADİL YARGILANMA HAKKI
}

DOI: https://doi.org/10.33717/deuhfd.899927

\author{
Arş. Gör. Seher ÇAKAN* \\ Dr. $\ddot{\text { ğr }}$. Üyesi Orçun AVCI ${ }^{* *}$
}

Öz

Vergilendirme süreci bir tarafinda mükelleflerin diğer tarafinda ise, devletlerin olduğu bir ilişkidir. Dolayısıyla bu ilişkide taraflar eşit değildir. Üstün güç konumunda olan devletler, vergilendirme yetkisini kullanarak çeşitli vergileri tahsil etmektedir. Ancak tarafların çıkarları arasında bir çatışma olması durumunda vergilendirme alanında mükellef hakları ön plâna çıkmaktadır. Avrupa Insan Hakları Mahkemesi mükelleflerin, ulusal mahkemeler tarafindan hak ihlâli ile karşılaştıklarında haklarının korunması hususunda başvurabilecekleri en önemli yollardan biridir. Mükellef haklarl Avrupa Insan Hakları Sözleşmesi'nde açıkça yer almamaktadır. Ancak Avrupa Insan Hakları Mahkemesi geliştirdiği içtihatlar yoluyla mükelleflerin haklarının korunmasını sağlamaktadır. Vergiler konusunda Avrupa Insan Haklart Mahkemesi'ne yaprlan hak ihlâli iddialarının büyük bir kısmı mülkiyet hakkı ve âdil yargılanma hakkı kapsamında olduğundan çalışmayı sınırlandırabilmek amacıyla bu iki hak üzerinde durulmaktadır. Bu çalışma, mükellef hakları bă̆lamında mülkiyet hakkı ve âdil yarglanma hakkını Avrupa Insan Hakları Mahkemesi'nin kararları çerçevesinde incelemektedir.

\section{Anahtar Kelimeler}

Avrupa Insan Haklarl Sözleşmesi, Avrupa Insan Haklarl Mahkemesi, Mükellef Haklarl, Mülkiyet Hakkı, Adil Yargılanma Hakkı

Aksaray Üniversitesi İktisadi ve İdari Bilimler Fakültesi, Siyaset Bilimi ve Kamu Yönetimi Bölümü, Hukuk Bilimleri Anabilim Dalı (e-posta: sehercakan_1905@) hotmail.com) ORCID: https://orcid.org/0000-0003-3254-6617 (Makalenin Geliş Tarihi: 06.02.2020) (Makale Gönderilme Tarihi: 07.02.2020/Makale Kabul Tarihi: 23.11.2020)

** Aksaray Üniversitesi İktisadi ve İdari Bilimler Fakültesi, Maliye Bölümü, Mali Hukuk Anabilim Dalı Öğretim Üyesi (e-posta: orcun.avci@outlook.com) ORCID: https://orcid.org/0000-0002-7917-9802 (Makalenin Geliş Tarihi: 06.02.2020) (Makale Gönderilme Tarihi: 07.02.2020/Makale Kabul Tarihi: 23.11.2020) 


\title{
TAXPAYER RIGHTS UNDER THE CASE LAW OF THE EUROPEAN COURT OF HUMAN RIGHTS: \\ THE RIGHT TO PROPERTY AND THE RIGHT TO A FAIR TRIAL
}

\begin{abstract}
The taxation process is a relationship with taxpayers on one side and states on the other. Hence, the parties are not equal in this relationship. States have power to collect various taxes. However, if there is a conflict between the interests of the parties, taxpayer rights come to the fore in the field of taxation. The European Court of Human Rights is one of the most significant legal remedies that taxpayers can apply in order to protect their rights which are violated by national courts. Taxpayer rights are not explicitly included in the European Convention on Human Rights. However, the European Court of Human Rights ensures the protection of the rights of taxpayers through the case law developed by the Court. Most of the alleged violation of rights to the The European Court of Human Rights on taxes are under the scope of property right and the right to a fair trial and for this reason, these two rights are explained in order to limit the study. This study examines the right to property and the right to a fair trial under the framework of the case law of the European Court of Human Rights in the context of taxpayer rights.
\end{abstract}

\section{Keywords}

The European Convention on Human Rights, The European Court of Human Rights, Taxpayer Rights, The Right to Property, The Right to a Fair Trial 


\section{GİRIŞ}

Hukuk devleti, yetkilerini hukuk kuralları ile sınırlandırmış, eşitlik ilkesine dayanan, idarenin tüm işlemlerinin denetime tâbi olduğu, insan haklarına saygılı bir devlet modelidir. Bu model içerisinde bazı durumlarda kişilerin hak ve özgürlüklerine birtakım müdahaleler söz konusu olabilmektedir. Ancak, bu müdahalenin de bir sınırı bulunmaktadır. Devlet tarafından kişilerin mülkiyet hakkına müdahale niteliği taşıyan vergilendirme işlemlerinin sınırları büyük önem arz etmektedir. Vergilendirme ilişkisi, tarafların eşit olmadığı, devletin üstün gücüne dayanan bir kamu hukuku ilişkisidir. Devletler, bu ilişkide egemenlik gücüne dayalı olarak kamu hizmetlerinin finansmanı amacıyla vergi toplamaktadır. Fakat bu süreçte, devletin amacı ile kişilerin menfaatleri karşı karşıya gelebilmektedir. Vergi ilişkisinin temelinde yatan menfaat çatışması ancak menfaatlerin karşılıklı dengelenmesi ile çözülebilecektir. Kişiler ile vergi idaresi arasındaki denge sağlanamadığı sürece sorun yaşanması muhtemeldir. Günümüzde birçok ülke, çeşitli hukukî araçlarla mükellef hakları konusunda düzenlemeler yapmaktadır. Burada amaç, mükelleflerin vergilemeden doğan haklarının tanımlanabilmesidir. Genel olarak bu haklar, mükelleflerin gönüllü uyumu ve idarenin mükellef odaklı bakmasını sağlayan haklar şeklinde düşünülebilir.

Mükellef hakları, vergilendirme sürecinde alacaklı idare ile mükellef arasındaki hukukî ilişkide yer alan hakları ifade etmektedir. Diğer bir deyişle, mükelleflere bir talepte bulunma yetkisi vermekte olup ihlâl edildiğinde mükelleflere hukukî koruma sağlayan haklardır. Hukukun genel ilkelerinden kaynaklanan temel mükellef hakları, âdil, eşit ve saygılı hizmet alma hakk1, bilgi alma hakkı, başvuru hakk1, mükelleflere ilişkin bilgilerin gizliliği hakkı ve özel hayatın gizliliği hakkıdır. Ancak vergi denetimi ve yargılaması sırasında da mükelleflerin bazı hakları bulunmaktadır. Vergilendirmenin tüm aşamasında karşımıza çıkan haklar ile mükelleflerin korunması amaçlanmaktadır.

Vergilendirme işlemleri sırasında meydana gelen vergi uyuşmazlıkları neticesinde çok sayıda hak ihlâli gündeme gelebilmektedir. Ancak, Avrupa İnsan Hakları Mahkemesi'ne en çok mülkiyet hakkı ve âdil yargılanma hakkının ihlâli ile ilgili başvuru yapılmaktadır. Bu kapsamda çalışmanın konusu, Avrupa İnsan Hakları Mahkemesi kararlarında mükellef hakları bağlamında mülkiyet hakkı ve âdil yargılanma hakkının incelenmesidir. Çalışmayla amaçlanan, mükelleflerin hakları konusunda yaşanan gelişmeler neticesinde Avrupa İnsan Hakları Mahkemesi nezdinde, vergi uyuşmazlıkları bakımından verilen içtihatlar incelenerek mülkiyet hakkı ve âdil yargılanma hakkı 
konusunda mükellef haklarının ortaya konulmasıdır. Çalışma yapılırken, doktrindeki görüşlerin yanı sıra, Avrupa İnsan Hakları Mahkemesi kararlarından yararlanılmakta ve mükellef hakları ile bağlantısı tartışılmaktadır. Çalışma kapsamında, mülkiyet hakkı genel olarak açıklanmaktadır. Avrupa İnsan Hakları Mahkemesi içtihatlarında mülkiyet hakkı ve sınırlandırılmasina yer verilerek Mahkeme'nin konu ile ilgili karar örneklerine yer verilmektedir. Ardından âdil yargılanma hakkı kapsamında mahkemeye erişim hakk1, mâkul sürede yargılanma hakkı ve hakkaniyete uygun yargılanma hakkına Mahkeme kararları 1şığında değinilmektedir.

\section{MÜLKIYYET HAKKI}

\section{A. Genel Açıklama}

Hukuk sistemleri ve hukuk ilmi ile uğraşanlar, tarih boyunca, bütün zaman, yer ve toplumlar için geçerli, değişmez bir mülkiyet kavramı ve tanımı aramıştır. Fakat, bunu bir türlü başaramamışlardır. İlk toplumdan bugüne kadar örf-âdet ve kavramların sürekli değişmesi ve gelişmesi bunun en temel sebebidir. Nitekim, mâlikin eşya üzerindeki yetki ve ödevleri çeşitli hukuk sistemlerine göre farklılık arz ettiği gibi, aynı milletin, hatta aynı devletin hukuk sistemi içinde dâhi mâlikin eşya üzerindeki hak ve ödevlerinin zamanla değişikliğe uğradığı görülmüştür ${ }^{1}$. Bu bağlamda mülkiyet kavramının kapsamının değişmesi mülkiyet hakkının gerek niteliğini gerekse de çerçevesini etkilemiştir. Günümüzde mülkiyet kavramının dinamik ve somut niteliği dolayısıyla üzerinde uzlaşılmış net bir tanımı olmadığı gibi mülkiyet hakkının niteliği, kapsamı ve sınırlandırma sebepleri itibariyle de uluslararası düzeyde ve devletler arasında önemli farklılıklar ortaya çıkmış$\operatorname{tir}^{2}$.

Bahsi geçen farkl1lıklara rağmen mülkiyet hakk1, temel bir hak olarak kabul edilmektedir. Temel haklar ve özgürlükler, pozitif hukuk düzeni tarafından tanınmış ve güvence altına alınmış, devletin koruyup geliştirmekle yükümlü olduğu insan hakları olarak ifade edilmektedir ${ }^{3}$. Diğer bütün hak-

1 Kamışlı, Gani: Avrupa İnsan Hakları Mahkemesi ve Anayasa Mahkemesi Kararları Işığında Mülkiyet Uyuşmazlıkları, Güncellenmiş ve Genişletilmiş 2. Baskı, Seçkin Yayıncılık, Ankara, 2018, s. 33; Oğuzman, Kemal/Barlas, Nami: Medeni Hukuk Giriş Kaynaklar Temel Kavramlar, 13. Bası, Arıkan Basım Yayım, Denizli, 2006, s. 105.

2 Karataş, Mustafa: “Anayasa Mahkemesi ve AİHM Kararları Işığında Vergilendirme Yoluyla Mülkiyet Hakkına Müdahalenin Sınırları", IX. Genç Vergi Hukukçuları Sempozyumu, 2019, s. 165.

3 Şahin, Kemal: “Avrupa İnsan Hakları Sözleşmesi Hukukunda, Doğal Afetlerde Yaşam Hakkı ve Mülkiyet Hakkı Bağlamında Devletin Sorumluluğu: Budayeva Kararı", 
ların kendisinden türediği kabul edilen mülkiyet hakkı, 19'uncu yüzyıla kadar mutlak ve sınırsız bir hak olarak değerlendirilmiştir. Ancak 20'nci yüzyıla gelindiğinde bu hakkın sınırsız olduğu düşüncesinden uzaklaşılmış ve mâlikine toplum yararına bazı ödev ve sorumluluklar yükleyen sosyal bir hak olduğu kabul edilmiştir ${ }^{4}$.

Mülkiyet hakkı, mükellef hakları ile doğrudan ilişki kurulabilecek en temel haklardan biridir. Çünkü, vergiler aracılığıyla doğrudan doğruya kişilerin mallarından devlet mülkiyetine bir geçiş söz konusu olmaktadır ${ }^{5}$. Bu hak güncel bir hak olup mutlak değildir ve böylece kamusal yetkileri kullanan kamu makamlarınca yapılacak olan müdahalelere açıktır ${ }^{6}$. Keyfî yapılacak müdahalelerden dolayı hem millî hem de devletlerarası mahkemeler tarafından teminat altına alınan bir haktır. Bu hak, Avrupa İnsan Hakları Sözleşmesi 1 No'lu Ek Protokol'ün 1'inci maddesinde düzenlenmiştir. Bu madde:

"Her gerçek ve tüzel kişinin mal ve mülk dokunulmazlığına saygı gösterilmesini isteme hakkı vardır. Bir kimse, ancak kamu yararı sebebiyle ve kanunda belirtilen şartlara ve devletlerarası hukukun genel ilkelerine uygun olarak mal ve mülkünden yoksun biraklabilir.

Yukarıdaki hükümler, devletlerin, mülkiyetin kamu yararına uygun olarak kullanılmasını düzenlemek veya vergilerin ya da başka katkıların veya para cezalarının ödenmesini sağlamak için gerekli gördükleri kanunları uygulama konusunda sahip oldukları hakka halel getirmez" şeklinde düzenlenmiştir ${ }^{7}$. Madde incelendiğinde, mülkiyet hakkına ilişkin ilk fikrada genel bir düzenlemeye yer verildiği ve ikinci fikrada ise, mutlak olmayan bu hakkın sınırlandırılabileceği anlaşılmaktadır.

Marmara Üniversitesi Hukuk Fakültesi Hukuk Araştırmaları Dergisi, 19(3), 2013, s. 57; Akça, Kürşat: “Anayasa Mahkemesi Kararlarında Mülkiyet Hakkı”, İnönü Üniversitesi Hukuk Fakültesi Dergisi, 1, 2015, s. 552.

4 Karataş, s. 165; Akıllığlu, Tekin: "Avrupa İnsan Hakları Mahkemesi Kararlarında Mülkiyet Hakkı ve Kazanılmış Hak Üzerine Bazı Gözlemler”, İdare Hukuku ve İlimleri Dergisi, 15(2), 2012, s. 10; Acu, Melek: "Bireysel Başvuruya Konu Edilebilecek Haklar", Türkiye Barolar Birliği Dergisi, (110), 2014, s. 424.

5 Er, Selami: "Mükellef Hakları ve Kamuda Faiz Uygulamaları”, Sayıştay Dergisi, (81), 2011, s. 6.

6 Gemalmaz, Haydar Burak: "Avrupa İnsan Hakları Sözleşmesi Açısından Mülkiyet Hakkının Sınırlanmasında 'Adil Denge' İlkesi”, İstanbul Üniversitesi Hukuk Fakültesi Mecmuas1, 69(1-2), 2011, s. 650.

7 Avrupa İnsan Hakları Sözleşmesi, Avrupa Antlaşmaları Serisi, No. 5, 2010, s. 32. 


\section{B. Avrupa İnsan Hakları Mahkemesi İçtihatlarında Mülkiyet Hakkı ve Sınırlandırılması}

1 No'lu Ek Protokol'ün 1'inci maddesi, Avrupa İnsan Hakları Sözleşmesi’nin vergi konusuna değinen tek maddesidir ${ }^{8}$. Bu maddeye göre, herkes mülkiyet hakkına sahiptir ve bu hak, kamu yararı ve hukuka uygun olarak sinırlandırabilir. Yine bu maddenin 2'nci fikrasında devletlere, vergilerin, para cezalarının ve diğer katkı paylarının ödenmesini sağlamak için gerekli gördükleri tedbirleri düzenleme yetkisi vermiştir. Diğer bir ifadeyle vergilendirme yetkisini düzenleyen bu fikra hükmüne göre, devletleri vergilerin konusunun, matrahının, mükellefinin, oranının belirlenmesinde tek yetkili makam olduğu gibi devletlere bu vergilerin tahsili için gerekli gördükleri tüm tedbirleri alma yetkisine de sahiptir ${ }^{9}$. Bir iktisadî değerin bu madde kapsamında vergilendirilmesi sadece devlet tarafindan tahsil edilmesini içermez, aynı zamanda devlet tarafından çıkarılan bir mevzuat hükmüne dayanarak kamu idareleri veya kamu kurumu niteliğindeki meslek kuruluşları tarafindan tahsil edilmesini de kapsamaktadir ${ }^{10}$.

Görüldüğü üzere, devletlerin vergilendirme yetkisi saklı tutulmaktadır. Vergilendirme yetkisini devlet olmanın temel ilkelerinden biri olarak gören Avrupa İnsan Hakları Mahkemesi, vergiyi kamu hizmetlerinin finansman1nın bir gereği olarak değerlendirmekte ve vergilendirme konusunda devletlere geniş bir takdir yetkisi alanı tanımaktadır. Bu takdir yetkisi sadece vergilerin konulması ya da kaldırılmasını değil, vergilerin ve diğer kamu gelirlerinin tahsili için gerekli tedbirlerin alınmasını da kapsamaktadır ${ }^{11}$.

Mülkiyet, mülkiyet hakkı ve bu hakkın Avrupa İnsan Hakları Sözleşmesi gibi ulusüstü hukukî metinlerle korunması bağlamında maddî ve gayri maddî malvarlığı değerlerinin yanında alacak hakları, vergi yükümlülükleri, ekonomik yaptırımlar gibi hususlar da bu kapsamda mülkiyet hakkı güvencesi dâhilindedir. Örneğin, vergi cezasına ilişkin bir hukukî uyuşmazlık

8 Dilemre Öden, Begüm: Avrupa İnsan Hakları Mahkemesi Kararlarının Türk Vergi Hukukuna Etkisi, 1. Bask1, Savaş Yayınevi, Ankara, 2017, ss. 94-95.

9 Şimşek, Suat: Türk Hukukunda ve Avrupa İnsan Hakları Sözleşmesinde Mülkiyet Hakkı, Hermes Matbaacılık, T.C. Maliye Bakanlığı Strateji Geliştirme Başkanlığı, Yayin No: 2011/413, Ankara, 2011, ss. 853-854.

10 Şimşek, Suat: "Vergi Politikaları, Mülkiyet Hakkı ve Avrupa İnsan Hakları Mahkemesi", Maliye Dergisi, 159 (Temmuz-Aralık), 2010, s. 325.

11 Dilemre Öden, Türk Vergi Hukukuna Etkisi, s. 160. 
hakkında Avrupa İnsan Hakları Mahkemesi'ne mülkiyet hakkının ihlâli iddiası ile başvuru yapılabilmektedir ${ }^{12}$.

Mükelleflerin mülkiyet haklarının ihlâl edilip edilmediğini Avrupa İnsan Hakları Mahkemesi, şu şekilde incelemektedir. İlk olarak, Avrupa İnsan Hakları Mahkemesi önüne gelen başvurudan dava konusunun 1 No'lu Ek Protokol'ün 1'inci maddesi anlamında mal olup olmadığını incelemektedir $^{13}$. Avrupa İnsan Hakları Mahkemesi kararlarına bakıldığında bu maddenin, sadece maddî varlığı olan taşınır ve taşınmazları değil aynı zamanda fizikî varlığı olmayan alacak hakları ve fikrî mülkiyet haklarını da kapsadığ1 görülmektedir ${ }^{14}$. Avrupa İnsan Hakları Mahkemesi, temelleri Roma Hukuku'na kadar uzanan geleneksel taşınır ve taşınmaz mülkiyet tanımlarını a-şarak, ekonomik içeriği ve parasal değeri olabilen hemen her konuyu mülkiyet hakk1 kapsamı içerisinde değerlendirme eğiliminde olmuştur ${ }^{15}$. Böylelikle Avrupa İnsan Hakları Mahkemesi, mülkiyet ve malvarlığı kavramlarını millî hukuktan bağımsız, özerk bir kavram olarak ele almaktadır.

Mülkiyet ve malvarlığ kavramlarının geniş şekilde kullanılmasının nedeni İngilizce ve Fransızca' da kullanılan "possessions" ve "biens" kelimelerinden kaynaklanmaktadır ${ }^{16}$. İngilizce' de possessions kavramı "korunan menfaati nitelemek" için kullanılırken ${ }^{17}$; Fransızca' da yer alan "biens" kavramı ise, "bütün miras yoluyla geçen haklar" için kullanılmaktadır ${ }^{18}$. Böylelikle de İngilizce metinde geçen "possessions" kelimesi, Fransızca metinde geçen "biens" kavramı nedeniyle dar yorumlanamaz ve bu kavram malvarlığına ilişkin geniş haklar dizisini koruma amacını içermektedir ${ }^{19}$.

12 Tabak, Bahadırhan: Mülkiyet Hakkı ve Anayasa Mahkemesinin Mülkiyet Hakkına Bakışı, Çankaya Üniversitesi, Sosyal Bilimler Enstitüsü, Kamu Hukuku Anabilim Dalı, Yüksek Lisans Tezi, Ankara, 2016, s. 7.

13 Yaltı, Billur: Vergi Yükümlüsünün Hakları, 1. Bası, Beta Basım Yayım Dağıtım, İstanbul, 2006, s. 47.

14 Bkz. Gasus Dosier und Fördertechnik GmbH v. Hollanda App No: 15375/89 (1995), paragraf 53.

15 Dinç, Güney: “Avrupa İnsan Hakları Sözleşmesi ve Mülkiyet Hakkı”, Türkiye Barolar Birliği Dergisi, (51), 2004, s. 134.

16 Şimşek, Vergi Politikaları, s. 326.

17 Yaltı, s. 48.

18 Grgić, Aida/Mataga, Zvonimir/Longar, Matija/Vilfan, Ana: Avrupa İnsan Hakları Sözleşmesi Kapsamında Mülkiyet Hakkı Avrupa İnsan Hakları Sözleşmesi ve Ek Protokollerinin Uygulanmasına İlişkin Kılavuz Kitap, Avrupa Konseyi İnsan Hakları El Kitapları, (Çeviren: Özgür Heval Çinar ve Abdulcelil Kaya), Numara 10, Haziran, Belçika, 2007, s. 8.

19 Yaltı, s. 48. 
Avrupa İnsan Hakları Mahkemesi, 1 No'lu Ek Protokol'ün 1'inci maddesini sadece mevcut malvarlı̆g 1 için uygulamakta olup "mal ve mülk elde etme hakkını garanti altına almadığını" belirtmektedir ${ }^{20}$. Ancak başvurucunun gerçekleşebilecek "meşru bir beklenti" içinde olduğunu ispatlaması şartıyla her türlü mal ve mülk bu madde kapsamına dâhil edilmektedir ${ }^{21}$.

İkinci olarak Avrupa İnsan Hakları Mahkemesi, mülkiyete yapılan müdahalenin meşru bir müdahale olup olmadığını değerlendirir. Bu bağlamda ilk olarak, müdahalenin hukuk tarafindan düzenlenip düzenlenmediğini ele alır. Hukuk tarafından yapılmış olan ilgili düzenleme yazılı olabileceği gibi Anglo-Sakson sisteminde olduğu gibi teamüle dayalı bir kural da olabilir. Bu nokta da önemli olan düzenlemenin alenî; yani, düzenlemelerin herkes tarafindan ulaşılabilir olması ve öngörülebilir olmasıdır. Diğer bir ifade ile, kuralın uygulanması halinde doğacak sonuçlarının tahmin edilebilir olması gerekir $^{22}$. Daha sonra, mülkiyete yapılan müdahalenin kamu yararına uygun olması gerekir. Avrupa İnsan Hakları Mahkemesi, "kamu yararı" kavramını tanımlamaktan kaçınmakta olup bu konuda taraf devletlere geniş bir takdir alanı bırakmaktadır. Böylece Mahkeme, "kavramı tanımlamak yerine, mülkiyet hakkına yapılan müdahale kapsamındaki uygulamanın kamu yararı amacıyla yapılıp yapılmadĭ̆ $\imath$ " konusunda bir değerlendirme yapmaktadır ${ }^{23}$. Vergilere ilişkin getirilen kural ve uygulamaların, vergi kaçakçıllğı ve vergiden kaçınmanın önlenmesi, verginin tahsilatının kolaylaştırılması, peçeleme işlemlerinin önlenmesi gibi pek çok meşru amacı vardır ${ }^{24}$. Ancak söz konusu amaçlar meşru olsa bile yani kamu yararına hizmet etme amacı taşısa bile kişilerin mülkiyet hakkının ihlâl edilmesine sebep olabilir. Bu noktada da müdahalenin orantılı ve ölçülü olması son şart olarak gündeme gelmektedir. Müdahalenin ölçülü ve orantılı olmasından kasıt ise, "müdahale ile ulaşılmak istenen amaç ile söz konusu amaca ulaşmada kullanılan araç arasındaki dengenin" olmasıdır ${ }^{25}$. Bu araçlar arasında bir denge sağlana-

20 Grgić/Mataga/Longar/Vilfan, s. 6.

21 Grgić/Mataga/Longar/Vilfan, s. 8.

22 Dilemre Öden, Türk Vergi Hukukuna Etkisi, s. 97.

23 Odabaş Sağır, Esin: Avrupa İnsan Hakları Sözleşmesi Çerçevesinde Gerçek Kişilerin Mülkiyet Hakkı, Beykent Üniversitesi, Sosyal Bilimler Enstitüsü, Hukuk Anabilim Dalı, Yüksek Lisans Tezi, İstanbul, 2016, s. 55.

24 Dilemre Öden, Türk Vergi Hukukuna Etkisi, s. 95.

25 Ertutar, Ege: "Vergi Uyuşmazlıkları Kapsamında Mülkiyet Hakkının Avrupa İnsan Hakları Mahkemesi Nezdinde Değerlendirilmesi”, http://www.ksavukatlik.com/vergiuyusmazliklari-kapsaminda-mulkiyet-hakkinin-avrupa-insan-haklari-mahkemesi-

nezdinde-degerlendirilmesi/, E.T.: 18.08.2020; Perdecioğlu, İsmail Emrah: Mülkiyet 
mamış olması halinde, mülkiyet hakkı ihlâl edilmiş olmaktadır. Genel veya kamu yararı ile şahsî yarar arasındaki dengenin sağlanması gerekmektedir. Sadece kamu yararını sağlamak için kişilere aşırı bir yük yüklenmemelidir.

Üçüncü olarak Avrupa İnsan Hakları Mahkemesi, üç kural analizi denilen metodla mülkiyet hakkının ihlâl edilip edilmediğini değerlendirir. İlk kuralda "mülkiyetten barışçıl bir şekilde yararlandırma ilkesi" yer alır; ikinci kuralda "mülkiyetten yoksun bırakma" düzenlenmiştir ve son kuralda da hukuka uygun olmak şartıyla kamu yararını gerçekleştirmek için "mülkiyetin kullanılmasını kontrol etme" yetkisi vardır" 26 . Bu üç kural da birbirleriyle ilgilidir.

Son olarak da, Avrupa İnsan Hakları Mahkemesi mülkiyet hakkı ichlâlinin olup olmadığının tespiti için Sözleşmeci Devletlerin takdir yetkisini aşıp aşmadığını araştırmaktadır. Avrupa İnsan Hakları Mahkemesi kendini Sözleşmeci Devlet yerine koymamakta ve devletlerin takdir yetkisine, sosyal ve ekonomik alanda aldığı kararlara saygı duyup sadece Avrupa İnsan Hakları Sözleşmesi'ne uygunluk yönünden denetlemektedir ${ }^{27}$. Devletlerin takdir yetkisi, vergilerin konulması ya da kaldırılması ile ilgili olabileceği gibi vergilerin ve diğer kamu gelirlerinin tahsili için gerekli tedbirlerin alınmasını da kapsamaktadır ${ }^{28}$. Söz konusu tedbirler, hukukî dayanaktan yoksun olmama11dır. Yukarıda değinilen tüm şartların sağlanması gerekmektedir. Aksi takdirde devletler, kişilerin mülkiyet hakkını ihlâl etmiş olmaktadır.

\section{Avrupa İnsan Hakları Mahkemesi Karar Örnekleri}

Avrupa İnsan Hakları Mahkemesi 1 No'lu Ek Protokol'ün 1'inci maddesi kapsamında mükellef hakları ile ilgili olarak vermiş olduğu önemli bazı kararlar ise şunlardır:

- Gasus Dosier und Fördertechnik GmbH v. Hollanda davasında, Gasus Doiser und Fördertechnik GmbH Alman şirketi, Hollandalı Atlas firmasına beton mikseri ve yardımcı ekipmanları satmış ve satış sözleşmesine malların mülkiyetinin ücreti tamamen ödeninceye kadar kendisinde kalacağı şartını

Hakk1 Yönünden Devletin Pozitif Yükümlülükleri, Birinci Bask1, Adalet Yayınevi, Ankara, 2020, s. 131.

26 Sporrong ve Lönnroth v. İsveç App No: 7151/75; 7152/75 (1982), paragraf 61; Perdecioğlu, s. 116.

27 Yücel, Özge: “Avrupa İnsan Hakları Sözleşmesi’ne Göre Kamulaştırmasız El Atma”, Prof. Dr. Tunçer Karamustafaoğlu'na Armağan, Adalet Yayınevi, Ankara, 2010, http://www.turkhukuksitesi.com/makale_1281.htm, E. T.: 04.04.2019. 
eklemiştir. Ancak Atlas firmasının vergi borcu nedeniyle Hollanda Vergi İdaresi, firmanın bütün taşınırlarını icra yoluyla satış için haczetmiş ve satmıştır. Mülkiyet hakkının ihlâl edildiği gerekçesiyle yapılan başvuruda Avrupa İnsan Hakları Mahkemesi, vergi idaresinin üçüncü kişilere ait mallardan vergi tahsil etme yetkisinin 1 No'lu Ek Protokol'ün 1'inci maddesi kapsamına dâhil olduğunu belirtmiş ve söz konusu vergi tahsilinde kamu yararı ile şahsî yarar arasında âdil bir dengenin kurulamadığı anlamına gelmeyeceğini ifade etmiştir ${ }^{29}$. Burada önemli olan husus, vergi idaresinin eylemlerinin sonucunda satıcının "şahsî ve aşırı bir yüke" katlanmış olup olmadığının tespit edilmesidir ${ }^{30}$. Avrupa İnsan Hakları Mahkemesi, başvurucu şirketin risk unsuru taşıyan bir ticarete girdiğini ve söz konusu riskin yeterince farkında olduğunu vurgulamıştır ${ }^{31}$. Avrupa İnsan Hakları Mahkemesi'ne göre başvurucu şirket, Atlas firmasına kredi vermeyi reddederek riskini ortadan kaldırabilirdi; başvurucu şirket ödemenin önceden yapılmasını şart koşabilirdi ya da satışı yapmayabilirdi ${ }^{32}$. Avrupa İnsan Hakları Mahkemesi aynı zamanda başvurucu şirketin banka teminatı gibi ek güvencelere de başvurabileceğini belirtmiştir ${ }^{33}$. Sonuç olarak da, şirket üzerine düşenleri gerektiği gibi yapmamış ve Avrupa İnsan Hakları Mahkemesi'ne göre orantıllılık şartı sağlandığı için 1 No'lu Ek Protokol'ün 1'inci maddesi ihlâl edilmemiştir.

- Bulves v. Bulgaristan ${ }^{34}$ kararında Bulves bir anonim şirket olup bir başka şirketten mal satın almıştır. Bulves, satın alınan mal bedelini ve katma değer vergisini (KDV) satıcı şirkete ödemiş ve bu işlemleri defterlerine kaydetmiştir. Ancak satıcı şirket, defter kaydını alıcı şirketten farklı bir tarihte yapması nedeniyle başvurucu KDV'yi faiziyle birlikte tekrar ödemek zorunda kalmıştır. Bu nedenle de alıcı şirket, 1 No'lu Ek Protokol'ün 1'inci maddesi kapsamında mülkiyet hakkının ihlâl edildiği gerekçesiyle Avrupa İnsan Hakları Mahkemesi'ne başvurmuştur. Mahkemeye göre, başvurucu şirket KDV raporlama yükümlülüklerini zamanında ve tam olarak yerine getirmiştir. Mahkeme başvurucunun, satıcı şirketin KDV bildirim yükümlülüklerini zamanında yerine getirmemesinin tüm sonuçlarını alıcı şirketin üstlenmek zorunda kalmasının başvurucu için aşırı şahsî bir yük oluştura-

Gasus Dosier und Fördertechnik GmbH v. Hollanda, paragraf 66. Gasus Dosier und Fördertechnik GmbH v. Hollanda, paragraf 67. Gasus Dosier und Fördertechnik GmbH v. Hollanda, paragraf 70. Gasus Dosier und Fördertechnik GmbH v. Hollanda, paragraf 70. Gasus Dosier und Fördertechnik GmbH v. Hollanda, paragraf 70. App No: 3991/03 (2009). 
cağını değerlendirmiştir ${ }^{35}$. Böylece Avrupa İnsan Hakları Mahkemesi başvuranın mülkiyet hakkının ihlâl edildiğine karar vermiştir.

- S.A. Dangeville v. Fransa ${ }^{36}$ davasında, başvurucu bir sigorta aracılık şirketidir ve 1978 yılında yüksek bir tutarda KDV ödemiştir. 1 Ocak 1978'de yürürlüğe giren Avrupa Toplulukları Altıncı Yönergesi’nin 13-B(a) maddesi, sigorta acentası ve aracı şirketler tarafından yapılan her tür işlem de dâhil, sigorta ve reasürans işlemlerinden muaf tutulmuştur. Bu yönergenin geçmişe etkili sonuç doğurmayacağı belirtilmiş ve 1 Ocak-30 Haziran 1978 tarihleri arasında uygulanması zorunlu tutulmuştur. Bunun üzerine başvurucu şirket Altıncı Yönergeye dayanarak ödediği KDV'nin iadesine ve bunun iç hukuka uygulanmamasından dolayı doğan zararının tazmini için dava açmıştır. Ancak, iç hukukta açılan davalar reddedilmiştir. Avrupa İnsan Hakları Mahkemesi'ne göre, mülkiyet hakkına müdahale herhangi bir meşru müdahaleden kaynaklanmamakta aksine yönergenin iç hukuka uygulanmamasından kaynaklanmaktadır ${ }^{37}$. Fransız yetkililer 2 Ocak 1976 tarihli idarî sirküler ile Altıncı Yönerge'yi iç hukukla uyumlu hale getirmeyi amaçlamıştır. Ancak, bunu 2 Ocak 1986 tarihine kadar yapamamıştır ${ }^{38}$. Avrupa İnsan Hakları Mahkemesi söz konusu yönergenin iç hukukta uygulanmamasından dolayı mülkiyet hakkının ihlâl edildiğine karar vermiştir.

- Bir başka davada ise, vergi iadesi taleplerinin geç yerine getirilmesi Avrupa İnsan Hakları Mahkemesi'ne konu olmuştur. Eko-Elda AVEE davasında ${ }^{39}$ başvurucu limited şirkettir ve $1988^{\prime}$ de kurumlar vergisini fazla ödediği gerekçesiyle fazla ödenen kısmın geri ödenmesini talep etmiştir. Ulusal mahkemede açılan dava devam ederken 1993'te iade gerçekleşmiş ancak başvurucunun yasal faiz talebi, Kamu Gelirleri Tahsilat Kanunu kapsamında düzenlenmediği gerekçesiyle reddedilmiştir ${ }^{40}$. Başvurucu 1 No'lu Ek Protokol'ün 1'inci maddesinin ihlâli gerekçesiyle Avrupa İnsan Hakları Mahkemesi'ne başvurmuştur. Avrupa İnsan Hakları Mahkemesi'ne göre, fazla ödenen vergi iade talebinden beş yıl sonra ödenmiştir ve Avrupa İnsan Hakları Mahkemesi de bu kadar geç yapılan ödemeden dolayı şahsî yarar ve kamu yararı arasında âdil bir dengenin kurulamadığı gerekçesiyle hak ihlâline karar vermiştir ${ }^{41}$.

\footnotetext{
35

Bulves v. Bulgaristan, paragraf 71.

App No: $36677 / 97$ (2002).

S.A. Dangeville v. Fransa, paragraf 57.

S.A. Dangeville v. Fransa, paragraf 57.

Eko-Elda AVEE v. Yunanistan App No: 10162/02 (2006).

Eko-Elda AVEE v. Yunanistan, paragraf 16 ve 18.

Eko-Elda AVEE v. Yunanistan, paragraf 31.
} 
- Önalım hakkının kullanılmasının vergilendirme aracılığıyla mülkiyet hakkına müdahale olup olmadığı da Avrupa İnsan Hakları Mahkemesi tarafindan incelenen konulardan biridir. Hentrich davasında ${ }^{42}$ başvurucu 1979 yılında imarsız arsa satın almıştır. Söz konusu arsanın satışı için SAFER'e (Bölgesel Kalkınma ve Kırsal Yerleşim Kurumu) iki aylık süre içerisinde kullanmak şartıyla önalım hakkı verilmiştir. Gerekli tüm işlemler yapılmış ve SAFER'in bu sürede önalım hakkını kullanmamasıyla sözleşme yürürlüğe girmiştir. 1980'de yani iki aylık süre geçtikten sonra SAFER önalım hakkını kullanacağını bildirmiştir. Başka bir ifadeyle, vergi kaçakçılığının önlenmesi amacıyla devlete önalım hakkı verilmiştir. Avrupa İnsan Hakları Mahkemesi'ne göre önalım hakkı, devlet egemenliğinin bir özelliği olarak eleştiriye neden olmazken, önalım hakkının kullanımı keyfî olmadıkça ve aynı zamanda âdil bir usûl kullanılmadıkça aynı şeyi söylemek mümkün değildir ${ }^{43}$. Avrupa İnsan Hakları Mahkemesi, SAFER'in önalım hakkının sırf diğer kişileri vergi kaçırmaya karşı uyarmak için herhangi bir alıcının özellikle de iyiniyetli alıcının yerine geçemeyeceğini belirtmiş olup hiçbir Sözleşmeci Devlet tarafindan böyle bir sistemin kullanılmadığını vurgulamış$\mathrm{tır}^{44}$. Vergi kaçırılmasının önlenmesi için önalım hakkı yerine caydırıcı başka cezalar verilebilir; örneğin ödenmeyen verginin tahsili için yasal bir prosedür konulabilir ve gerekirse vergi cezaları da uygulanabilir ${ }^{45}$. Diğer bir ifadeyle devlet, vergi kaçakçılığını önlemek için önalım hakkını kullanmak yerine dava açma, para cezası uygulanması gibi yöntemlere başvurabilir. Sonuç olarak Avrupa İnsan Hakları Mahkemesi başvurucunun aşırı şahsî bir yüke maruz kaldığg gerekçesiyle hak ihlâli olduğuna karar vermiştir.

- Avrupa İnsan Hakları Mahkemesi, iç hukuktaki mevzuatın belirsiz olması nedeniyle 1 No'lu Ek Protokol'ün 1'inci maddesinin ihlâl edilebileceğini ve bu bağlamda da verginin öngörülebilirliğini Serkov v. Ukrayna ${ }^{46}$ davasında vurgulamıştır. Olayda, başvurucu KDV'yi ödemiş, daha sonra çıkarılan mevzuata göre vergiyi ödemekten muaf olduğunu iddia etmiştir. Neden olarak da bu hukukî düzenlemelerin ulusal mahkemeler tarafindan farklı yorumlanmasına dayandırmışıtır ${ }^{47}$. Avrupa İnsan Hakları Mahke-

\footnotetext{
42 Hentrich v. Fransa App No: 13616/88 (1994).

43 Hentrich v. Fransa, paragraf 42.

44 Hentrich v. Fransa, paragraf 47.

45 Hentrich v. Fransa, paragraf 47.

46 App No: 39766/05 (2011).

47 Serkov v. Ukrayna, paragraf 37 (Çeviren: Sarıcaoğlu, Ercan: “AİHM'in Vergilerin Kanuniliğinde Öngörülebilirlik İlkesine Bakışı, Avrupa İnsan Hakları Mahkemesi 5. Daire Serkov-Ukrayna Davası (Başvuru No: 39766/05)", Küresel Bakış, 1(3), 2011, ss. 140-141).
} 
mesi'ne göre, iç hukukta kanunun emsal yorumu haklı nedenlere dayand1rılarak zamanla değişebilir ${ }^{48}$. Avrupa İnsan Hakları Mahkemesi'ne göre, mevzuatın belirsiz olması veya birden fazla yoruma açık hükümler içermesi durumunda mükellefin lehine olanın kabul edilmesi gerekmektedir ${ }^{49}$. Fakat ulusal mahkemeler mükellefin lehine yorumlamadığı için 1 No'lu Ek Protokol'ün 1'inci maddesi ihlâl edilmiştir.

- Son olarak da N.K.M. v. Macaristan ${ }^{50}$ davas1, incelenmesi gereken bir davadır. Çünkü, bu davada Avrupa İnsan Hakları Mahkemesi vergi aslını mülkiyet hakkı bağlamında ele almıştır. İlgili davada başvurucu 30 yıldır çalışan bir devlet memuru olup kamudaki önlemler çerçevesinde işten çıkartılmıştır. İlgili mevzuata göre işten çıkartılmasının karşılığı olarak da 8 aylık maaşına denk gelen kısım kadar tazminata hak kazanmıştır. Ancak başvurucunun tazminatının 3.5 milyon Macar Forinti’ni aşan kısmı \% 98 oranında vergiye tâbi tutulmuştur. Avrupa İnsan Hakları Mahkemesi kıdem tazminatını 1 No'lu Ek Protokol'ün 1'inci maddesi kapsamında malvarlığ olarak kabul etmiştir ${ }^{51}$. Genel olarak Macaristan'da gelir vergisi \% 16 olup başvurucu yaklaşık \% 52 oranında vergiye tâbi tutulmuştur ${ }^{52}$. Avrupa İnsan Hakları Mahkemesi’ne göre başvurucuya aşırı bir yük getirilmiş olup yüksek vergi oranının bütçe açığını düzeltmek amacına hizmet edildiği düşünülse bile vatandaşların çoğu için böyle bir durum söz konusu değildir ${ }^{53}$. Alınan tüm önlemler sosyal adaleti gerçekleştirmek için alınmış olmasına karşın kamu yararı temelde meşrulaşmamıştır ve söz konusu önlemler orantısız$\mathrm{d}_{1}{ }^{54}$. Devletlerin vergi toplamasındaki temel amacı kamu yararını gerçekleştirmek olmasına rağmen, vergilendirmede orantısızlığın mülkiyet hakkını ihlâl edeceği sonucuna varılabilir.

Serkov v. Ukrayna, paragraf 39-40 (Çeviren: Sarıcaoğlu, s. 141).

Serkov v. Ukrayna, paragraf 43 (Çeviren: Sarıcaoğlu, s. 142).

App No: 66529/11 (2013). N.K.M. davasında aynı yönde görüş bildiren yargıçlara göre bir içtihat değişikliğine gidilmemiş olmasına rağmen (N.K.M. v. Macaristan, Concurring Opinion of Judge Lorenzen, p. 27.) ögrretide bu kararla birlikte Avrupa İnsan Hakları Mahkemesi'nin içtihat değişikliğine gittiği yönünde görüşler de vardır ve bu görüşe göre de Avrupa İnsan Hakları Mahkemesi mülkiyete vergisel konularda müdahalelere ilişkin pasif tutumunu değiştirmiştir (Gemalmaz, Haydar Burak: "Mali Güç Ölçütünü Dikkate Almayan Aşırı Vergi Mülkiyet Hakkı İhlalidir: Avrupa İnsan Hakları Mahkemesi'nin Macaristan'a Karşı 14 Mayıs 2013 Tarihinde Verdiği N.K.M. Kararının İncelenmesi”, İstanbul Barosu Dergisi, 88(2), 2014, ss. 129-130, 141).

N.K.M. v. Macaristan, paragraf 36.

N.K.M. v. Macaristan, paragraf 66.

N.K.M. v. Macaristan, paragraf 72.

N.K.M. v. Macaristan, paragraf 75. 
Mülkiyet hakkına ilişkin bahsedilen tüm hususlar dikkate alındığında mülkiyet hakkının ihlâl edilmesi mükellef hakkının ihlâli anlamına gelecektir. Bu bağlamda vergilerin konusunun, matrahının, oranının belirlenmesi gibi hususlarda yapılacak ihlâller mülkiyet hakkını doğrudan etkilemektedir. Keza Avrupa İnsan Hakları Mahkemesi vergilendirme işlemleriyle ilgili olarak mülkiyeti muhafaza kaydıyla satılan malın vergi idaresince müsadere edilmesini, vergi iadesi talebini, ek gelir vergisi tarhiyatını, vergi idaresinin taşınmaz üzerinde önalım hakkını kullanmasını mülkiyet hakkı kapsamında değerlendirmesi bu durumu doğrulamaktadır. Neticede Avrupa İnsan Hakları Sözleşmesi kapsamında mülkiyet hakkı, mükellef hakkı olarak karşımıza çıkmaktadır.

\section{ADİL YARGILANMA HAKKI}

\section{A. Genel Açıklama}

Bir insan hakkı olarak "âdil yargılanma hakkı" kavramının nasıl adlandırılması gerektiği ve hakkın tam olarak ne ifade ettiği doktrinde sıkça tartışılmıştır. Adaletin kendisinden beklenen işlevleri yerine getirebilmesi için uyulması gereken asgari standartlar âdil yargılanma hakkının kapsamını oluşturmaktadır ${ }^{55}$. Yargılamanın gerçekleri yansıtabilmesi için, uyuşmazlığın tarafları arasında fiilî ve hukukî bir fark gözetmeden, iddia ve savunmaların eşit ölçülerde ve karşılıklı olarak yapıldığı yargılama, âdil bir yargılamadır ${ }^{56}$.

Adil yargılanma hakkı, "tabiî hâkim ilkesine bağll, tarafsız ve bağımsız bir mahkeme tarafindan, makûl sürede, alenî ve hakkaniyete uygun olarak yargılanmayı talep edebilme" şeklinde tanımlanabiliir ${ }^{57}$. Bu hak sadece başlamış bir yargılamayı güvence altına almaz aynı zamanda bizzat dava etme hakkını da içerisinde barındırmaktadır ${ }^{58}$.

55 Çırak, Ezgi: “Avrupa İnsan Hakları Sözleşmesi Çerçevesinde Adil Yargılanma Hakkının Uygulama Alanı”, Dokuz Eylül Üniversitesi Hukuk Fakültesi Dergisi, Prof. Dr. Durmuş Tezcan'a Armağan, 21, 2019, s. 1002; Taner, Fahri Gökçen: Ceza Muhakemesi Hukukunda Adil Yargılanma Hakkı Bağlamında Çelişme ve Silahların Eşitliği, Birinci Baskı, Seçkin Yayıncılık, Ankara, 2019, s. 25.

56 Çırak, s. 1002.

57 Karakoç, Yusuf: Genel Vergi Hukuku, Gözden Geçirilmiş ve Genişletilmiş 7. Bası, Yetkin Yayınları, Ankara, 2014, s. 923; Karakoç, Yusuf: Vergi Yargılaması HukukuVergi Anlaşmazlıklarının/Uyuşmazlıklarının Çözüm Yolları, Gözden Geçirilmiş ve Genişletilmiş 4. Baskı, Yetkin Yayınları, Ankara, 2017, s. 278.

58 Uçan, Emine Sevcan: Avrupa İnsan Hakları Sözleşmesi Çerçevesinde Türk Vergi Yargılaması Hukukunda Adil Yargılanma Hakk1, Dokuz Eylül Üniversitesi, Sosyal Bilimler Enstitüsü, Kamu Hukuku Anabilim Dalı, Yüksek Lisans Tezi, İzmir, 2013, s. 9. 
Hak arama özgürlüğünün uygulamaya yönelik uzantısı olan âdil yargılanma hakkı, esasen adaletin dağıtımı ile değil adaletin âdil dağıtımı ile ilgilidir. Burada önemli olan âdil bir kararın verilip verilmediği değil, yargilama süreci boyunca âdil kararın verilmesi için gerekli olan şartların var olup olmadığıdır ${ }^{59}$. Avrupa İnsan Hakları Mahkemesi nezdinde hak arama yolunun geçici veya sürekli olarak fiilen ya da hukuken kapatılması yahut kullanımını imkânsız kılacak bir biçimde şartlara bağlanıp sınırlanması âdil yargılanma hakkını ihlâl edecektir ${ }^{60}$.

Günümüzde demokratik devlet olmanın vazgeçilmez unsurlarından biri haline gelen âdil yargılanma hakkı, hukuk devleti ilkesinin de en önemli gereklerindendir. Adil yargılanma hakkı, hukuk devleti ve adaletin en önemli koruyucularından birisidir. Bu bağlamda devletler, âdil yargılanma hakkını ya anayasalarında temel haklara ilişkin bölümünde belirterek ya da hukuk devleti kavramını geniş yorumlayarak güvence altına almaktadırlar ${ }^{61}$. Adil yargılanma hakkı aynı zamanda kişilerin hem devlet önünde saygı gördüklerinin göstergesi hem de içinde yaşadıkları toplumda kendilerini değerli hissetmelerinin en önemli gereğidir ${ }^{62}$.

\section{B. Adil Yargılanma Hakkının Hukukî Dayanağı ve Kapsamı}

Adil yargılanma hakkı Avrupa İnsan Hakları Sözleşmesi'nin 6'ncı maddesinde düzenlenmektedir ve bu maddeye göre:

"Herkes davasının, medeni hak ve yükümlülükleriyle ilgili uyuşmazlıklar ya da cezai alanda kendisine yöneltilen suçlamaların esası konusunda karar verecek olan, kanunla kurulmuş, bağımsız ve tarafsı bir mahkeme tarafindan, kamuya açı olarak ve makul bir süre içinde görülmesini isteme hakkina sahiptir. Karar alenî olarak verilir. Ancak, demokratik bir toplum içinde ahlâk, kamu düzeni veya millî güvenlik yararına, küçüklerin çıkarları veya bir davaya taraf olanların özel hayatlarının gizliliği gerektirdiğinde veyahut, aleniyetin âdil yargllamaya zarar verebileceği kimi özel durumlarda ve mahkemece bunun kaçınllmaz olarak değerlendirildiği ölçüde,

Pekcanıtez, Hakan: “Medeni Yargıda Adil Yargılama”, İzmir Barosu Dergisi, (2), 1997, s. 37; Gözler, Kemal: Anayasa Hukukuna Giriş, 18. Baskıdan Ek Baskı, Ekin Yayınevi, Bursa, 2012, s. 209; Bayraktar, Tuğba/Koyuncu, Nuran: “Adil Yargılanma Hakkı", 2nd International Congress on Political, Economic and Social Studies (ICPESS), 2017, s. 168.

60 Dilemre Öden, Begüm: "Vergi Mükelleflerinin Mahkemeye Erişim Hakkı", Vergi Sorunları Dergisi, (372), 2019, s. 126.

61 Sencer, Rasih Feridun: “Adil Yargılanma Hakk1”, İzmir Barosu Dergisi, 2013, s. 112.

62 Sencer, s. 113. 
duruşma salonu tüm dava süresince veya klsmen basina ve dinleyicilere kapattlabilit $^{63}$."

Adil yargılanma hakkı Sözleşme'de yer almasına rağmen, kavramın tanımı yapılmamıştır. Fakat Sözleşme'de var olan hak ve güvenceler bir bütün olarak âdil yargılanmayı sağlamayı amaçlamıştır. Keza bu hak kişiye usûlî güvenceler sağlamaktadır ve adaletin "âdil dağıtımı" ile ilgilidir ${ }^{64}$. Adil yargılanma hakk1, mahkemeye başvurma hakkı, silahların eşitliği (yargılama sürecinde tarafların eşitliği) ve çelişmeli yargılama ilkeleri, susma hakkı gibi hak ve ilkelerle bağlantılıdır ${ }^{65}$. Bu hakkın hangi uyusmazlıklara uygulanacağının tespiti en zor konulardan biridir. Çünkü, Sözleşmenin 6'ncı maddesinin uygulama alanına tüm yargılama süreçleri dâhil edilmemiş sadece bir kısmı dâhil edilmiștir. Bu hak "medenî hak ve yükümlülükler" ile "suç isnadı" süreçleri ile sınırlıdır ${ }^{66}$. Keza bu kavramların tanımları da Sözleşme'de yer almamaktadır. Söz konusu kavramların kapsamı her olaya göre, iç hukuktan bağımsız bir şekilde belirlenmektedir ${ }^{67}$.

Bir uyuşmazlığın "medenî hak ve yükümlülükler" kapsamında olması için tarafların özel hukuk kişisi olması gerekmediği gibi uyuşmazlığa uygulanacak kanunun niteliği ve o uyuşmazlığı karara bağlayacak olan makam da önemli değildir ${ }^{68}$. Burada önemli olan husus, uyuşmazlık konusu hakların

63 Avrupa İnsan Hakları Sözleşmesi, Avrupa Antlaşmaları Serisi, No. 5, 2010, s. 9; Centel, Nur: "Adil Yargılama İlkesi ve Türk Hukukundaki Bazı Sorunlar", Marmara Üniversitesi Hukuk Fakültesi Hukuk Araştırmaları Dergisi, 16(1-2), 2010, s. 6; Kup Belge, Kamuran: İdari Yarg1 Yönüyle Adil Yargılanma Hakkı, Ondokuz Mayıs Üniversitesi, Sosyal Bilimler Enstitüsü, Kamu Hukuku Anabilim Dalı, Yüksek Lisans Tezi, Samsun, 2019, s. 8.

64 Yaltı, s. 80

65 Yaltı, ss. 81-82.

66 Bkz. Tezcan, Durmuş/Erdem, Mustafa Ruhan/Sancakdar, Oğuz/Önok, R. Murat: İnsan Hakları El Kitabı, Genişletilmiş 5. Baskı, Seçkin Yayıncılık, Ankara, 2014, ss. 220-221; Doğru, Osman/Nalbant, Atilla: İnsan Hakları Avrupa Sözleşmesi Açılama ve Önemli Kararlar, Cilt 1, 2. Baskı, Yargıtay Başkanlığı ve Avrupa Konseyi Ortak Yayını, Ankara, 2013, s. 610; Çağıran, Mehmet Emin: Uluslararası Alanda İnsan Hakları, Genişletilmiş Gözden Geçirilmiş 4. Baskı, Turhan Kitabevi, Ankara, 2020, ss. 398-399.

67 Kartal, Kaya: “Adil Yargılanma Hakkı”, Genç Hukukçular Hukuk Okumaları, 2009, s. 48.

68 Arslan Öncü, Gülay: "Vergi Hukuku ve Yargılamasına Avrupa İnsan Hakları Sözleşmesinin Uygulanabilirliği: Avrupa İnsan Hakları Kararları Işı̆̆ında Bir Analiz”, TAAD, 6(20), 2015, s. 145; Demirkıran, Eyüp Kaan: "İnsan Hakları Avrupa Sözleşmesi ve 1982 Anayasası Bağlamında Etkili Başvuru Hakkı ve Adil Yargılanma Hakkının Kapsam Alanlarının Karşılaştırılması", Türk-Alman Üniversitesi Hukuk Fakültesi Dergisi, 2(1), 2020, s. 63. 
niteliğidir 69. "Medenî hak ve yükümlülüklerin" Sözleşme’nin 6(1) maddesi kapsamında değerlendirilmesi için ilk olarak bir uyuşmazlığın bulunması gerekir; ikinci olarak, söz konusu uyuşmazlık iç hukukta tanımlanmış olmalıdır ve son olarak da uyuşmazlık konusu "haklar ve yükümlülükler" Avrupa İnsan Hakları Sözleşmesi’ndeki anlamıyla medenî olmalıdır ${ }^{70}$.

Avrupa İnsan Hakları Mahkemesi, vergiye ilişkin düzenlemelerin kamu alanına özgü olması nedeniyle kamusal bir yükümlülük olarak medenî hak ve yükümlülük kapsamında değerlendirilmeyeceği görüşündedir ${ }^{71}$. Ancak Avrupa İnsan Hakları Mahkemesi'ne göre, Sözleşme'nin kabul edilmesinden bugüne kadar kişiyle devlet arasındaki ilişkiler birçok açıdan değişim göstermiş olup, kamu hukuku alanındaki bazı hususlar medenî haklar kapsamında ele alınmıştır ve bu duruma arsa satışı, özel bir hastanenin işletilmesi, mülkiyet hakkının kullanımı, alkollü içki satışı için lisans verilmesi örnek olarak gösterilebilir ${ }^{72}$. Avrupa İnsan Hakları Mahkemesi, vergilendirme ile ilgili gelişmeleri kabul etmekle birlikte vergi meselelerinin devletin halâ kamusal yetkisinin sert çekirdeği içinde yer aldığını ve vergi mükellefi ile devlet arasındaki ilişkinin kamusal niteliğinin ön plânda olduğunu kabul etmektedir $^{73}$. Ayrıca Avrupa İnsan Hakları Mahkemesi, Sözleşme ve Protokollerinin bir bütün olarak yorumlanması gerektiğini ve 1 No'lu Ek Protokol'ün 1'inci maddesi kapsamında devletin, mükelleflerin vergi yükümlülüklerini yerine getirmesi için gerekli düzenlemeler yapabileceğini belirtmektedir $^{74}$. Bu doğrultuda Ferrazzini davası medenî hak ve yükümlülüklerin vergiye ilişkin davalara da uygulanıp uygulanmayacağının tespitinde önemlidir. Bu davada başvurucu çiftlik tatili düzenlemek amacıyla kurduğu şirkete arsa, mülk ve para aktarmıştır. Başvurucu söz konusu aktarımları yaparken ilgili kanuna istinaden vergi merciîlerine başvurarak indirim yapılması için talepte bulunmuştur. Ancak başvurusu reddedilmiştir. Daha sonra başvurucu Avrupa İnsan Hakları Mahkemesi'ne, millî hukuk yargılamasının yaklaşık on üç yıl sürmesi nedeniyle âdil yargılanma hakkının ihlâl edildiği gerekçesiyle başvurmuştur. Avrupa İnsan Hakları Mahkemesi’ne göre, vergi

Doğru/Nalbant, s. 612; Kaşıkara, M. Serhat: “Avrupa İnsan Hakları Sözleşmesi’nin 6. Maddesi Çerçevesinde Makul Süre İçerisinde Yargılanma Hakkı", Türkiye Barolar Birliği Dergisi, (84), 2009, s. 241.

Doğru/Nalbant, s. 610; Cebre, Ayvaz: "Hak Arama Yolları ve Adil Yargılanma Hakkı", Türkiye Adalet Akademisi Dergisi, 1(5), 2011, s. 381.

71 Uçan, s. 32.

72 Ferrazzini v. İtalya, App No: $44759 / 98$ (2001), paragraf 27.

73 Ferrazzini v. İtalya, paragraf 29.

$74 \quad$ Ferrazzini v. İtalya, paragraf 29. 
davaları maddî menfaatlerle ilgilidir. Ancak, bir uyuşmazlığın nitelik itibariyle maddî olması tek başına madde 6(1)'deki “medenî” kapsamında değerlendirilmesi için yeterli değildir ${ }^{75}$.

Neticede Avrupa İnsan Hakları Mahkemesi, madde 6(1)'in medenî hak ve yükümlüklerin vergiye ilişkin uyuşmazlıklara uygulanmayacağına karar vermiştir $^{76}$. Ancak Mahkeme'nin olağan vergilendirme işlemlerinin madde 6(1) kapsamında değerlendirilmeyeceği yönünde içtihadı olsa da vergilendirme işlemlerinin sonucu olarak uğranılan zararın tazminine yönelik uyuşmazlıkları medenî hak ve yükümlülük kapsamına alıp bu madde çerçevesinde dikkate de aldığı görülmektedir ${ }^{77}$.

Mükellefler vergi suç ve kabahatleri sonucunda hapis ya da para cezasıyla cezalandırılmaktadır. Bu nedenle de vergi cezalarının Avrupa İnsan Hakları Sözleşmesi'nde belirtilen suç isnadı dâhilinde olup olmadığı gündeme gelmektedir. Suç isnadı kavramı da Avrupa İnsan Hakları Sözleşmesi'nde tanımlanmayarak kapsamı belirtilmemiştir. Bu kavram da otonom (özerk) bir kavramdır ve Avrupa İnsan Hakları Mahkemesi'nin içtihatları doğrultusunda suç isnadının belirlenmesine dair ölçütler geliştirilmiştir. Bir isnadın Sözleşme kapsamında "suç isnadı" olup olmadığ için de Avrupa İnsan Hakları Mahkemesi üç ölçüt kullanmaktadır; "suçun iç hukuktaki yeri”, "suçun gerçek niteliği" ve "suç için öngörülen cezanın niteliği ve ağırlı̆̆ı(dır) ${ }^{78}$ ". Bunlara ek olarak, aşağıda belirtilen dört unsurun bulunması halinde madde 6(1) vergi cezalarına da uygulanmaktadır ve söz konusu unsurlar şöyledir: "(1)vergi para cezalarını düzenleyen kanun, vergi mükellefleri olan bütün vatandaşları kapsamall;(2) vergi para cezası bir zarara karşılık maddi tazminat amacı değil, fakat esas itibarlyla yeniden suç işlemeyi caydirıcı bir ceza amacı taşımalı; (3)ceza hem caydırıcı hem de cezalandırıcı genel bir kurala göre verilmiş olmall; ve (4) vergi para cezası önemli olmalıdır ${ }^{79}$ ". Sözleşme'nin madde 6(1) hükmünün vergi cezalarına uygulanabilmesine rağmen, salt vergi matrahı veya yeniden suç işlenmesini caydırmak yerine esas itibariyle vergi makamlarına verilen zararın tazmin amacını taşıyan geç ödeme sonucunda uygulanan faiz ile ilgili davalar

Ferrazzini v. İtalya, paragraf 25.

Ferrazzini v. İtalya, paragraf 29-30.

77 Dilemre Öden, Türk Vergi Hukukuna Etkisi, s. 224.

78 Doğru/Nalbant, s. 616; Çayan, Gökhan: Adil Yargılanma Hakkı, Birinci Basım, Legal Yayınc1l1k, İstanbul, 2016, s. 37.

79

Doğru/Nalbant, s. 617. 
kapsam dışındadır ${ }^{80}$. Suç isnadının madde 6(1) kapsamında olduğu kabul edilmiş ancak idarî para cezalarının bu kapsamda olup olmadığı tartışılmıştır. Bu konuyu da Avrupa İnsan Hakları Mahkemesi ilk kez Bendenoun v. Fransa $^{81}$ davasında açıklık getirmiş olup vergi cezalarının suç isnadı olarak kabul edileceğini belirtmiştir.

\section{Mahkemeye Erişim Hakkı}

Mahkemeye erişim hakkı, kişilerin iddia ve savunmalarını bir yargı mercii önünde ileri sürebilmelerine imkân sağlayan ve âdil yargılanma hakkının bir unsuru olarak kabul edilen bir haktır ${ }^{82}$. En genel anlamıla bir mahkeme kararı elde edebilme hakkını güvence altına almaktadır ${ }^{83}$.

Mahkemeye erişim hakkı, iç hukukta var olan bütün mahkemelere ulaşma hakkını kapsamaktadır. Benzer şekilde genel olarak kabul edildiği gibi iç hukukta kişinin şahsına özgü haklarını korumaya yönelik başvuracağ 1 bir yarg1 yolunun olmaması da bu hak dâhilindedir. Bu hak, mutlak bir hak olmayıp sınırlamalara tâbidir ve bu sınırlama Sözleşmeye taraf devletler tarafından kişilerin ihtiyaçları ve topluma göre belirlenir ama bu sınırlamalar kişilerin bu hakkının özüne dokunmamalıdır ${ }^{84}$. Buna ek olarak, sınırlama meşru bir amaç gütmeli ve kullanılan araçlarla gerçekleştirilmek istenen amaç arasında makûl bir oran olmalıdır. Mahkemeye başvurmada "makûl bir oranlılık ilişkisi" çerçevesinde harç ödemelerinin söz konusu olması, bu duruma bir örnektir. Millî kanun koyucunun bu yetkiyi meşru bir amaç çerçevesinde kullanıp kullanmadığı Avrupa İnsan Hakları Mahkemesi tarafından tespit edilmektedir ${ }^{85}$.

Mahkemeye erişim hakkı, açıç̧a madde 6(1)'de ifade edilmemiş olmasına rağmen Avrupa İnsan Hakları Mahkemesi hukukun üstünlüğünden

$80 \quad$ Doğru/Nalbant, s. 617.

81 App No: 12547/86 (1994). Adı geçen karar Yargılama Sürecinde Tarafların Eşitliği ve Çelişmeli Yargılama İlkeleri başlığı altında açıklanmaktadır.

82 Ekinci, Ahmet: “Anayasa Mahkemesi’nin Bireysel Başvuru Kararlarında Mahkemeye Erişim Hakkı”, Gazi Üniversitesi Hukuk Fakültesi Dergisi, 18(3-4), 2014, s. 823; Aydın, Alper: "Mahkemeye Erişim Hakkı Işı̆̆ında Vergi Mahkemelerinde Dava Açma Süreleri", Türkiye Adalet Akademisi Dergisi, (34), 2018, s. 539.

83 Çayan, Gökhan: “Avrupa İnsan Hakları Mahkemesi ve Anayasa Mahkemesi Kararları Işı̆̆ında Mahkemeye Erişim Hakkı”, Türkiye Adalet Akademisi Dergisi, (28), 2016, s. 238.

84 Golder v. Birleşik Krallık App No: 4451/70 (1975), paragraf 38.

85 Hoşten, Zamira: "Anayasa Mahkemesi ve AİHM Kararları Çerçevesinde Adil Yargilanma Hakkı”, Terazi Hukuk Dergisi, 14(156), 2019, s. 1546. 
yola çıkarak, bu hakkın madde 6(1) kapsamında olduğunu kabul etmektedir $^{86}$. Avrupa İnsan Hakları Mahkemesi'ne göre:

"Medeni hak uyuşmazlıklarında mahkemeye başvurma ihtimalinin bulunmadiğl yerde hukukun üstünlügünü tasavvur etmek zordur...Sözleşmenin 6/1'inci maddesi, sadece, bir mahkeme önünde zaten başlatılmış olan bir davanın görülmesine ilişkin olarak anlaşılsaydl, bir Sözleşmeci Devlet söz konusu metni ihlal etmeksizin, mahkemeleri kapatabilir, ya da bunların medeni nitelikteki belirli olaylara ilişkin davaları karara bağlama yetkilerini alıp, hükümete bağll organlara verebilirdi. Böylesi yetkiler keyfi iktidar tehlikesi ile birlikte, yukarıda belirtilen ilkelere aykır nitelikte, Mahkemenin görmezden gelemeyeceği ciddi sonuçlar doğururdu. Mahkemeye göre Sözleşmenin 6/1'inci maddesinin görülmekte olan dava için taraflara tanıdığ usul güvencelerini ayrıntıl olarak tanımlarken bu tür güvencelerden yararlanmayı mümkün kılan mahkemeye başvurmayı korumaması düşünülemez. Ĕger ortada bir dava yoksa, yargılamanın adil, aleni ve süratli olmasinın hiçbir anlamı kalmayacaktır... ${ }^{87}$."

Janosevic karar ${ }^{88}$ mahkemeye erişim hakkı bakımından Avrupa İnsan Hakları Mahkemesi'nin verdiği kararlardan biridir. Bu kararda başvurucu bir taksi işletmecisi olup vergi beyannamesindeki usûlsüzlük nedeniyle vergi dairesi tarafından ek vergi ödemesine karar verilmiştir. Bunun üzerine başvurucu ek matrahın yanlış hesaplandığını ve tarhiyat hakkında mahkeme karar verinceye kadar yürütmenin durdurulmasını talep etmiştir. Çünkü başvurucu, mahkeme karar vermeden önce işletmenin iflâs etme riski olduğunu iddia etmiştir. Ancak, başvurucunun söz konusu talebi ve diğer başvuruları reddedilmiştir. Mevcut olayda Janosevic vergi tarh işleminin yeniden incelenmesi için vergi idaresine itirazda bulunmuştur. Fakat, bu itirazdan sonra icra işlemleri başlatılmış ve mahkemenin nihaî bir kararı olmadan iflâsı ilân edilmiştir. Avrupa İnsan Hakları Mahkemesi, vergi idaresinin gözden geçirme işleminin yaklaşık 3 yıl sürdüğünü, davanın şartlarının gerektirdiği ivedilikle yapılmadığını ve bunun sonucu olarak da ek vergi konulması hakkında esas meselenin mahkemece belirlenmeksizin gereksiz bir şekilde geciktirdiği gerekçesiyle davacının mahkemeye erişim hakkının ihlâl edildiğine karar vermiştir ${ }^{89}$.

\footnotetext{
$86 \quad$ Yaltı, s. 114.

87 Başaran, Başar: Adil Yargılanma Hakkı, Ankara Üniversitesi, Sosyal Bilimler Enstitüsü, Kamu Hukuku Anabilim Dalı, Yüksek Lisans Tezi, Ankara, 2007, s. 59. Janosevic v. İsveç App No: $34619 / 97$ (2002).

Janosevic v. İsveç, paragraf 90. Ayrıca bkz. Mahkemeye erişme hakkının ihlâli Vastberga Taxi Aktiebolag ve Vulic v. İsveç App No: 36985/97 (2002).
} 
Mahkemeye erişim hakkı kişilerin iddialarını ve savunmalarını yarg1 mercii önünde savunma hakkı veren bir haktır. Ancak bu hak mutlak değildir ve bu nedenle de sınırlandırılabilir. Sınırlandırmanın yapılabilmesi için Avrupa İnsan Hakları Mahkemesi bazı ölçütler geliştirmiştir. İlk olarak yapılacak sınırlandırmalar, bu hakkın özüne dokunmamalıdır. İkinci olarak, sınırlama meşru bir amaç gütmelidir. Son olarak ise, kullanılan araçlarla gerçekleştirilen amaç arasında makûl bir oran olması gerekmektedir. Bahsi geçen üç ölçütten birinin gerçekleşmemesi halinde mahkeye erişim hakk1 ihlâl edilmiş olacaktır.

\section{Ç. Makûl Sürede Yargılanma Hakkı}

$\mathrm{Bu}$ hak, tarafları yargılama işlemlerinin sürüncemede kalmasına karş1 korumaktadır. Avrupa İnsan Hakları Mahkemesi, makûl sürede yargılanma hakkının ceza ve hukuk davalarını kapsadığını; fakat, vergi aslına ilişkin yargılama sürelerinin 6'ncı madde kapsamında değerlendirilmediğini belirtmektedir $^{90}$. Vergi yargılamalarının uzun sürmesi hem kişi hem de devlet bütçesinde zarara sebebiyet vermesi bakımından bu davaların makûl sürede yapılması önemli bir konu olarak karşımıza çıkmaktadır ${ }^{91}$. Yine genel olarak "makûl süre", adaletin etkinliğini ve inanılırlığını zayıflatabilecek gecikmeler olmaksızın, bir ceza veya medenî hukuk ya da idarî bir davanın makûl bir süre içinde görülmesini sağlayan bir güvence olarak görülmektedir ${ }^{92}$. Başka bir deyişle, davanın açılması ile kararın verilmesi arasında geçen sürenin uzun olması kamunun adalet sistemine inancinın sarsılmasına sebep olur. Bu hak, kişilerin menfaatlerini iki şekilde korumayı hedeflemektedir. Öncelikle kişiler, kendi gelecekleri hakkında uzun bir süre belirsizlik altında kalmaktan kurtulmaktadır. İkinci olarak, kişilerin etkin bir savunma yapabilmesini sağlamaktadır ${ }^{93}$.

Yaltı, s. 121; Özkan Duvan, Ayşe: "Bireysel Başvuru Kararlarında Makul Sürede Yargılanma Hakkı", Ankara Üniversitesi Hukuk Fakültesi Dergisi, 68(1), 2019, s. 287.

91 Uçan, s. 92; Şahin, İsmail: “Anayasa Mahkemesi Kararlarında Makul Sürede Yarg1lanma Hakkının İhlali”, Yıldırım Beyzıt Hukuk Dergisi, (1), 2019, s. 226; Gölcüklü, Feyyaz: “Avrupa İnsan Hakları Sözleşmesinde Kişi Özgürlüğü ve Güvenliği”, Ankara Üniversitesi Siyasal Bilgiler Fakültesi Dergisi, 49(3), 1994, s. 213; Doğmuş, Simay: "Vergi Uyuşmazlıkları Bakımından Makul Sürede Yargılanma Hakkı", Çankaya Üniversitesi Hukuk Fakültesi Dergisi, 5(1), 2020, s. 1152.

92 Keskin, Bayram: "İdari Yargılamada Makul Süre Kavramının Avrupa İnsan Hakları Mahkemesi Kararları Işı̆̆ında İncelenmesi”, İnönü Üniversitesi Hukuk Fakültesi Dergisi, 9(2), 2018, s. 395; Özkan Duvan, s. 290.

93 Özgüven, Ali Volkan: “Adil Yargılanma İlkesi ve Vergi İhtilaflarındaki Uygulaması-I”, Vergi Sorunları Dergisi, (197), 2005, s. 198; Turan, Hüseyin: “Avrupa İnsan Hakları 
Genel olarak, bir yargılamanın makûl olup olmadığı her somut olaya göre ayrı bir şekilde değerlendirilmektedir. Örneğin, kan nakli yapılan ve AİDS hastalığı bulaşan bir kişinin yaptığı başvuruda Avrupa İnsan Hakları Mahkemesi, millî mahkemede davanın yirmi bir ay sürmesini, hastanın sağlık durumunu dikkate almak suretiyle, makûl süre aşımı olarak kabul ederek mahkûmiyet kararı vermiştir. Ancak Avrupa İnsan Hakları Mahkemesi, her davada geçerli olabilecek mutlak bir süre belirlememiş olmasına rağmen ceza ve hukuk davaları bakımından bazı tespitler yapmıştır. Avrupa İnsan Hakları Mahkemesi içtihatlarına göre, makûl sürenin başlangıcı ceza davalarında kişi hakkında bir suç isnadının yapıldığı an kabul edilir ve bu süre davanın nihaî olarak karara bağlandığı ana kadar devam eder. Hukukî ve idarî davalarda ise, süre kural olarak mahkemeye davanın getirildiği anda başlar. Fakat Avrupa İnsan Hakları Mahkemesi bazı durumlarda sürenin daha önce başlayabileceğini König v. Almanya ${ }^{94}$ davasında belirtmiştir. Söz konusu tespitlere ek olarak Mahkeme, bir sürenin makûl olup olmadığının değerlendirilmesinde bazı ölçütleri de kabul etmiştir. Bunlar: "davanın karmaşıklığı", "başvurucunun tutumu", "yetkili idarî makamların ve yargı m-ercilerinin tutumudur" ${ }^{\prime 95}$.

Özetle makûl sürede yargılanma hakk1, her somut olaya göre değerlendirilmektedir. Dolayısıyla vergi davaları için de kesin bir makûl süre tespiti yapmak mümkün değildir. Olay fazla karmaşıksa, pek çok belgenin incelenmesini ve tanığın dinlenmesini gerektiriyorsa, bu yargılamanın uzaması makûl olarak değerlendirilebilecektir. Eğer mükellef kendi kusuruyla buna sebep olmuşsa, kendi kusurlu hareketinden lehine sonuç çıkarması mümkün değildir ${ }^{96}$. Başka bir deyişle, bazı durumlarda başvuran, gereksiz deliller sunarak veya tanıklar dinleterek yargılama sürecini uzatmaya çalışması durumunda makûl sürede yargılanma hakkının ihlâl edildiğini iddia edemez ${ }^{97}$.

Hozee davas ${ }^{98}$ vergi mükelleflerinin hakları kapsamında makûl sürede yargılanma hakkına örnek olarak gösterilebilir. Olayda başvurucunun şirketlerinde inceleme başlatılmış ve ardından vergi kaçakçılığ 1 şüphesi ile takibat

\footnotetext{
Mahkemesi İçtihatlarında Makul Sürede Yargılanma Hakkı”, Türkiye Adalet Akademisi Dergisi, (11), 2012, s. 51.

Dilemre Öden, Türk Vergi Hukukuna Etkisi, s. 307.

Dilemre Öden, Türk Vergi Hukukuna Etkisi, s. 307.

Hozee v. Hollanda App No: 81/1997/865/1076 (1998).
} 
yapılmıştır. 31.12.1981 tarihinde şirkete ek vergi tarh edilmiş ve 1981-1984 tarihleri arasında şirket bünyesinde incelemeler yapılmıştır. 1984'te başvurucu sorguya alınmış, soruşturma 1985 'te başlamış ve 01.12.1992 tarihine kadar sürmüştür. Başvurucu makûl sürede yargılamanın yapılmadığını özellikle de dava öncesi soruşturma aşamasının uzun sürdüğü gerekçesiyle madde 6(1)'in ihlâl edildiğini ileri sürmüştür. Avrupa İnsan Hakları Mahkemesi makûl süre başlangıcı olarak, başvurucunun suç süphesi ile sorguya alındığı 1984 yılını dikkate almış, 1984-1992 yılları arasındaki dönemin makûl olup olmadığını incelemiştir. Avrupa İnsan Hakları Mahkemesi'ne göre, yetkililer vergi kaçakçılığını tespit için çok fazla hesap incelemiştir ve yine davanın açılabilmesi için çok fazla tanıktan delil toplamıştır. Tüm unsurları bir araya getirerek, hepsini incelemek zorunda kalmışlardır ${ }^{99}$. Daha sonraki aşamada başka şüphelilerin iştirakiyle dava daha kapsamlı bir hâl almıştır ve bu nedenle dava öncesi geçen sürenin makûl olmadığı sonucuna varılmamalıdır ${ }^{100}$. Davanın karara bağlanması aşamasında 3 yıl 10, 5 haftalık bir süre geçmiştir ve bu süre de uzun bir süre değildir ${ }^{101}$. Avrupa İnsan Hakları Mahkemesi, söz konusu hususlar dikkate alındığında ihlâl olmadığına karar vermiştir.

\section{Hakkaniyete Uygun Yargılanma Hakkı}

\section{Genel Açıklama}

Hakkaniyete uygun yargılanma hakkı Avrupa İnsan Hakları Mahkemesi içtihatlarıyla oluşturulmuştur. Bu hak, tüm önemli olgu ve hukukî meseleleri yeterli biçimde ortaya koyabilme, bu hususta delil ileri sürebilme, yargılamaya katılan başka kişilerin görüşlerinden ve delillerinden bilgi sahibi olabilme imkânı vermektedir ${ }^{102}$. Hakkaniyete uygun yargılanma hakk1, yarg1lama sürecinde tarafların eşitliği ve çelişmeli yargı ilkeleri, suçlu olduğu kanitlanıncaya kadar masum sayılma hakk1, susma hakk1, tanıkların sorgulanması ve tanık dinlenilmesi hakkı gibi çeşitli hakları kapsamaktadır ${ }^{103}$. Söz konusu haklar, alt başlıklarda detaylı bir biçimde ele alınmaktadır.

\footnotetext{
99 Hozee v. Hollanda, paragraf 52.

100 Hozee v. Hollanda, paragraf 52.

101 Hozee v. Hollanda, paragraf 53.

102 Tezcan/Erdem/Sancakdar/Önok, s. 234.

103 Hakkaniyete uygun yargılanma hakkı; hukukî dinlenilme hakkı, avukatla temsil hakk1, aleni yargılanma hakk1, tercümandan yararlanma hakk1 ve gerekçeli karar hakkı gibi hakları bünyesinde barındıran geniş bir kavramdır. Bu nedenle bahsi geçen haklara konuyu sınırlandırabilmek adına yer verilmemiştir.
} 


\section{Yargılama Sürecinde Tarafların Eşitliği ve Çelişmeli Yargılama Illkeleri}

\section{a. Genel Açıklama}

Yargilama sürecinde tarafların eşitliği ilkesi felsefi olarak muhakeme hukuku alanında bir doğal hukuk ilkesidir ve bu ilke, eşitlik, adalet ve hukuk devleti kuralları arasındaki bölünmez bağı ifade etmesi sebebiyle muhakeme hukukunda gerçek bir doğal hukuk ilkesini oluşturmaktadır ${ }^{104}$.

Mahkeme önünde sahip olunan haklar ve yükümlülükler bakımından, taraflar arasında tam bir eşitliğin sağlanması ve bu dengenin yargılamanın tüm aşamalarında korunması yargılamanın hakkaniyete uygun yapılması bakımından önemlidir. Yargılama sürecinde tarafların eşitliği ilkesi olarak isimlendirilen bu ilke Avrupa İnsan Hakları Sözleşmesi'nde açıkça zikredilmese de hakkaniyete uygun yargılanmanın bir gereği olarak Mahkeme'nin içtihatlarında yer edinmiştir ${ }^{105}$.

Yargılama sürecinde tarafların eşitliği ilkesi hem ceza davalarında hem de şahsî haklarla ilgili davalarda uygulanmaktadır. Avrupa İnsan Hakları Mahkemesi'ne göre, yargılama sürecinde tarafların eşitliği ilkesi geniş anlamda âdil yargılamanın bir unsuru olup taraflardan her birine kendi davalarını savunma hususunda diğerine karşı dezavantajlı bir duruma düşmemesi için makûl firsatların verilmesini gerektirmektedir ${ }^{106}$. Böylelikle, savunma ve iddia makamına eşit imkânlar tanınıp eşit muamelede bulunmalı ve taraflara aynı çerçevede bilgi verilerek aynı şartlar altında kendilerini savunma imkânı tanınmalıdır ${ }^{107}$. Yargılama sürecinde tarafların eşitliği ilkesi, usûle ilişkin hakları güvence altına almaz. Ancak bu usûle ilişkin hak taraflar arasında bir adaletsizliğe neden olmuşsa, eşitliğin sağlanması için bu ilkeye başvurulmaktadır ${ }^{108}$.

Çelişmeli yargılama ilkesi, "bir hukuk ya da ceza davasında tüm taraflara, mahkemenin kararını etkilemek amacıyla ulusal yargının bağımsız bir mensubu tarafindan bile olsa gösterilen kanitlar ve sunulan görüşlerle

\footnotetext{
104 Tezcan, Durmuş: “AİHM'in Silahların Eşitliği Kapsamında, Göç-Türkiye Davasıyla Başlayan Sürece Nihat Ateş-Türkiye Davasıyla Getirdiği Yeni Anlayış”, Yakın Doğu Üniversitesi Hukuk Fakültesi Dergisi, Prof. Dr. Yıldırım Uler'e Armağan, 2014, s. 528.

Uçan, s. 97; Vitkauskas, Dovydas/Dikov, Grigoriy: Avrupa İnsan Hakları Sözleşmesi Kapsamında Adil Yargılama Hakkının Korunmas1, Avrupa Konseyi İnsan Haklar1 El Kitaplar1, (Çeviren: Serkan Cengiz), Strazburg, 2012, s. 55.

106 Kress v. Fransa App No: 39594/98 (2001), paragraf 72.

107 Tezcan/Erdem/Sancakdar/Önok, s. 235. 
ilgili bilgiye sahip olma ve bunlarla ilgili görüş bildirebilme hakkının tanınması" anlamına gelmektedir ${ }^{109}$. Çelişmeli yargılama ilkesi de yargılama sürecinde tarafların eşitliği ilkesi gibi Avrupa İnsan Hakları Sözleşmesi'nde açıcça düzenlenmemiştir ${ }^{10}$. Davanın sonucunu etkiler nitelikteki bir bilginin, belgenin ya da delilin tarafların incelemesine sunulmadan ulusal mahkemelerce hükme esas tutulması yargılamanın hakkaniyete uygunluğunu şüpheye düşüreceğinden, çelişmeli yargılama hakkı, âdil yargılanma hakk1nın alt başlığı olan hakkaniyete uygun yargılanma kapsamında değerlendirilmektedir ${ }^{111}$.

\section{b. Avrupa İnsan Haklart Mahkemesi Karar Örnekleri}

Yargılama sürecinde tarafların eşitliği ve çelişmeli yargılama ilkeleri ile ilgili aşağıdaki kararlar örnek olarak verilebilir:

- $J J$ v. Hollanda ${ }^{112}$ davasında karşı görüş bildirme imkânının tanınmadığı gerekçesiyle Avrupa İnsan Hakları Mahkemesi’ne başvurulmuştur. Başvurucuya cezalı gelir vergisi tarhiyatı yapılmıştır. Başvurucu, İstinaf Mahkemesi'ne itirazda bulunmuş; fakat, mahkeme harcı yatırmadığı gerekçesiyle itirazı reddetmiştir. Başvurucu ise, harcın ödenmemesinin ilgili bankanın hatası olduğunu, kendisinin bundan dolayı sorumlu tutulamayacağını belirtmiştir. Avrupa İnsan Hakları Mahkemesi'ne göre, Yüksek Mahkeme'den önceki yargılamada başvurucu hakkında bir cezai isnat söz konusudur ve Hollanda Yüksek Mahkemesi'nin tâbi olduğu usûl kuralları dikkate alındığında savcının mütalâasının çok önemli olduğu görülmektedir ${ }^{113}$. Bu bağlamda başvurucu Yüksek Mahkeme Başsavcısının mütalâasına karşı cevap verememesi sonucu davaya katılma hakkı ihlâl edilmiştir ${ }^{114}$.

- Diğer bir örnekte Miailhe v. Fransa (No:2) kararıdır. Olayda başvurucunun şirket merkezinde ve Filipinler Fahri Konsolosluğunda gümrük görevlileri arama yapmış ve çok sayıda belgeye el koymuştur. Arama ve el koyma, sadece malî denetimle sınırlı olmayıp aynı zamanda başvurucunun

10 Sevdiren, Öznur: "Çeliş̧meli Yargılama ve Silahların Eşitliği İlkeleri Bağlamında Teşhis İşlemi ve Bu İşlemde Müdafiin Hazır Bulunma Yetkisi”, Galatasaray Üniversitesi Hukuk Fakültesi Dergisi, (1), 2019, s. 33.

111 Güngör, Burak: Silahların Eşitliği İlkesi ve Çelişmeli Yargılama Hakkı'nın Bireysel Başvuru Usulünde İncelenmesi, Kocaeli Üniversitesi, Sosyal Bilimler Enstitüsü, Kamu Hukuku Anabilim Dal1, Doktora Tezi, Kocaeli, 2019, s. 152.

112 App No: 21351/93 (1998).

113 JJ v. Hollanda, paragraf 42.

114 JJ v. Hollanda, paragraf 43.
} 
Fransa'da ikamet edip etmediğinin soruşturulmasını da kapsamaktadır. Başvurucu, hapis cezasına çarptırılmış ve el konulan belgeleri de iade edilmiştir. Başvurucu Gelir İdaresi'nin elindeki tüm belgelere ulaşamadığını ve bu nedenle kendini savunamadığını iddia ederek yargılama sürecinde tarafların eşitliği ilkesine aykırılık iddiasıyla Avrupa İnsan Hakları Mahkemesi'ne başvurmuştur ${ }^{115}$. Avrupa İnsan Hakları Mahkemesi, başvurucunun hem Fransa'daki hem de Filipinler'deki belgelere ulaşma imkânının olduğu sonucuna varmıştır ${ }^{116}$. Davayı millî mahkemeler, kendi sınırları içinde inceleyip yalnızca dosyada yer alan ve tarafların ortaya koyduğu belgelere dayanarak hüküm vermiştir ${ }^{117}$. Sonuç olarak da başvurucu âdil bir şekilde yargılanmış ve 6'ncı madde ihlâl edilmemiştir.

- Bendenoun v. Fransa davasında başvurucu, aleyhine açılan davalarda idarenin elindeki bütün bilgi ve belgelere ulaşamamış olduğunu iddia etmiştir. Bendenoun, yetkililerin kendisiyle ilgili olan dosyanın tamamını vermediğini ve böylelikle kendini aklayamadığını iddia etmiştir. Avrupa İnsan Hakları Mahkemesi, âdil bir yargılama için hazinenin de belli belgeleri davacıya verme yükümlülüğünün olduğunu ve temel belgelerin davaciya verilmesi gerektiğini vurgulamıştır ${ }^{118}$. Avrupa İnsan Hakları Mahkemesi, başvurucunun kendisi ile ilgili temel belgelerin bir nüshasına ulaşmadan vergi kaçakçılığı suçuyla suçlanamayacağını belirtmiştir ${ }^{119}$. Ancak Avrupa İnsan Hakları Mahkemesi, Bendenoun'un çoğu belgenin varlığından ve içeriğinden haberdar olup en azından ceza soruşturması sırasındaki tüm belgelere sahip olduğu sonucuna varmıştır ${ }^{120}$. Böylelikle Avrupa İnsan Hakları Mahkemesi'ne göre, âdil yargılanma hakkı ihlâl edilmemiştir.

\section{Diğer Haklar}

\section{a. Genel Açıklama}

Çalışmanın bu alt başlığında hakkaniyete uygun yargılanma hakkına ilişkin, suçlu olduğu kanıtlanıncaya kadar masum sayılma hakkı, susma hakkı, tanıkların sorgulanması ve tanık dinlenilmesi hakkı incelenmektedir.

\footnotetext{
115 Turinay, Faruk: “Avrupa İnsan Hakları Mahkemesi'nin 1996 Tarihli Miailhe V. Fransa Kararı Üzerine Bir İnceleme”, Ankara Barosu Dergisi, (3), 2014, s. 341.

116 Turinay, ss. 343-344.

117 Turinay, s. 343.

118 Bendenoun v. Fransa, paragraf 52.

119 Bendenoun v. Fransa, paragraf 52.

120 Bendenoun v. Fransa, paragraf 52.
} 


\section{b. Masum Sayılma Hakk}

Sözleşmenin 6'nc1 maddesinin 2'nci fikrasına göre, "Bir suç ile itham edilen herkes, suçluluğu yasal olarak sabit oluncaya kadar masum sayılır", şeklinde ifade edilmiştir ${ }^{121}$. Avrupa İnsan Hakları Mahkemesi içtihatlarına göre, bir kişinin hem suçlu olduğu ispatlanmamış hem de kendisine savunma hakk1 verilmemişse masumiyet karinesi ihlâl edilmektedir ${ }^{122}$. Ayrıca Avrupa İnsan Hakları Mahkemesi, bu hakkın sadece mahkemeler tarafından değil aynı zamanda diğer kamu makamları tarafından da ihlâl edilebileceğini belirtmektedir. Avrupa İnsan Hakları Mahkemesi’ne göre, “...Bir mahkemenin üyelerinin, görevlerini yerine getirirken, sanı̆̆ın kendisine isnad edilen suçu işlediği iddiasıyla işe başlamamaları gerekir; ispat külfeti iddia makamına aittir ve her türlü şüpheden sanık yararlanır. Ayrıca, iddia makamının, aleyhinde yapılacak davayı sanığa bildirmesi, böylece sanık, savunmasını buna göre hazırlayıp sunabilecek ve mahkum edilmemek için yeterli delil sunacaktır" ${ }^{, 23}$.

- A.P., M.P. ve T.P. v. Ísviçre ${ }^{124}$ kararında miras bırakana ölmeden önce vergi kaçakçılığı nedeniyle para cezası kesilmiş ve bu ceza miras bırakanın varislerinden istenmiştir. Başvurucular, miras bırakanın işlediği suçtan dolay1, kendilerinin sorumlu tutulamayacaklarını iddia etmişlerdir. Avrupa İnsan Hakları Mahkemesi, ölen bir kimsenin diğer borçlarında olduğu gibi, vergi borcunun da terekeden tahsil edilebilmesinin olağan olduğunu belirtmiş ancak ölen bir kimseye verilen para cezasının mirasçılardan alınmasının bahsedilen durumdan farklı olduğunu ifade etmiştir ${ }^{125}$. Başka bir deyişle, cezaların şahsîliği ilkesi gereği, vergi cezaları ölümle birlikte sona ermektedir. Suç işleyen bir kimsenin işlediği suçla ilgili cezaî sorumluluğunun ölümünden sonra devam etmemesi ceza hukukunda kabul edilen temel bir prensip olup İsviçre Hukuku'nda da bulunmaktadır ${ }^{126}$. İsviçre Ceza Kanunu madde 48(3)'te, suçlunun ölümü hâlinde verilen para cezasının ortadan

121 Avrupa İnsan Hakları Sözleşmesi, Avrupa Antlaşmaları Serisi, No. 5, 2010, s. 10; Iş̧k, Hüseyin: "Suçsuzluk Karinesi”, Uyuşmazlık Mahkemesi Dergisi, (1), 2012, s. 118.

Değirmencioğlu, Burcu: “Avrupa İnsan Hakları Mahkemesi İçtihatları Işı̆̆ında "Masumiyet Karinesi”nin Korunması", Ankara Sosyal Bilimler Üniversitesi Hukuk Fakültesi Dergisi, (2), 2019, s. 310.

123 Barbera, Messegue ve Jabardo v. İspanya App No: 10590/83 (1988), paragraf 77; Ormanoğlu, Hatice Derya: “Anayasal Bağlamda ve Avrupa İnsan Hakları Sözleşmesi Boyutuyla Suçsuzluk Karinesi”, Ankara Üniversitesi Hukuk Fakültesi Dergisi, 65(4), 2016, s. 2246.

124 App No: 71/1996/690/882 (1997).

125 A.P., M.P. ve T.P. v. İsviçre, paragraf 46.

126 A.P., M.P. ve T.P. v. İsviçre, paragraf 48. 
kalktığı yer almaktadır ve Avrupa İnsan Hakları Mahkemesi böyle bir kuralın Sözleşme'nin madde 6(2) kapsamında olduğunu ifade etmiştir ${ }^{127}$. Bu bağlamda da maddenin ihlâl edildiği sonucuna varılmıştır.

\section{c. Susma Hakkı}

Susma hakk1, âdil yargılanmaya ilişkin bir diğer haktır. Susma hakk1, "kişinin kendini suçlayıcı bir duruma düşmesine yol açacak şekilde zorlanmama hakkının bulunduğunu ifade eder",28. Susma hakkının iki yönü olup bunlardan birincisi hiç kimsenin kendini suçlayıcı belge ve/veya ifadeyi yetkili makamlara vermeme hakkını kapsarken, ikincisi ise kişinin sessiz kalmasının aleyhinde delil olarak kullanılmamasına ilişkindir ${ }^{129}$. Susma hakkı, bir suç isnadı varsa açık bir şekilde madde 6(1) kapsamında olmalı$\operatorname{dır}^{130}$. Ceza davalarında iddia makamının, kişiyi zorlamadan ve ona zarar vermeden sanık aleyhinde olan delilleri toplaması gerekir. Bununla bağlantılı olarak, susma hakkının, kendi kendini suçlayıcı delilleri vermeme hakkının bir uzantısı olarak isbat hukukuyla yakından ilişkili olduğu açıktır ${ }^{131}$.

Susma hakk1 hem Sözleşme'nin 6'ncı maddesinde hem de Avrupa İnsan Hakları Sözleşmesi'nin genelinde açıkça yer almamaktadır. Avrupa İnsan Hakları Mahkemesi, susma hakkını âdil yargılanma kapsamında degerlendirmektedir ${ }^{132}$. Avrupa İnsan Hakları Mahkemesi, bu hakk1 ilk kez Funke davasında ${ }^{133}$ madde 6(1) kapsamında incelemiş ve Saunders ${ }^{134}$ ve John Murray ${ }^{135}$ davalarında bu içtihadını geliştirmiştir.

A.P., M.P. ve T.P. v. İsviçre, paragraf 48.

Yaltı, s. 139; İnce Tunçer, Asuman: "Susma Hakkı Bağlamında Birtakım Ceza Muhakemesi İşlemlerinin Değerlendirilmesi”, Anadolu Üniversitesi Hukuk Fakültesi Dergisi, 4(2), 2018, s. 357; Haydar, Nuran: Susma Hakkı, Seçkin Yayıncılık, Ankara, 2019, s. 29.

129 Ayrıca susma hakkı, "hiçbir şüpheli ve sanık konuşmaya veya kendini suç altına sokmaya zorlanamaz" ilkesinden gelen evrensel bir haktır (Yaltı, s. 139; Kocaoğlu, Serhat Sinan: "Susma Hakk1", Ankara Barosu Dergisi, (1), 2011, s. 31; Demirbaş, Timur: "Soruşturma Evresinde Şüphelinin İfadesi Alınması ve Müdafilik", Legal Hukuk Dergisi, (32), 2005, s. 2878.

Baker, Philip: "Taxation and the European Convention on Human Rights", British Tax Review, 2000, http://www.fieldtax.com/wp-content/uploads/2015/04/BTR-2000-4-211377-Taxation-and-the-European-Convention-on-Human-Rights.pdf, E. T.: 12.04.2019.

Yaltı, s. 140; Kan Aydın, Çağrı: "Adil Yargılanmanın Bir Unsuru Olarak Susma Hakkı”, Türkiye Barolar Birliği Dergisi, (91), 2010, s. 159.

Bkz. J.B. v. İsviçre App No: $31827 / 96$ (2001).

Funke v. Fransa App No: 10828/84 (1993).

Saunders v. Birleşik Krallık App No: $19187 / 91$ (1996).

John Murray v. Birleşik Krallık App No: 18731/91 (1996). 
Avrupa İnsan Hakları Mahkemesi'ne göre susma hakkı, Sözleşme'nin 6'ncı maddesinde açıkça ifade edilmemiş olmasına rağmen, susma hakkı ve kendi kendini suçlamama hakkı genel olarak uluslararası standartlarda tanınmış olup 6'ncı maddenin de temelini oluşturmaktadır ${ }^{136}$. Bu hakkın amacı, sanığın yetkililer tarafından uygun olmayan zorlamalara karşı korunması olup böylelikle hem adlî hatanın önlenmesini hem de 6'ncı maddenin amacının gerçekleştirilmesini sağlar ${ }^{137}$. Kendi kendini suçlamama hakk1 özellikle, iddia makamının, cezaî bir soruşturma yaparken, sanığa karşı, onun iradesi hilâfına, baskı ve zorlama olmadan, iddia makamının kendi iddiasını isbat etmesi gereğine dayanır ${ }^{138}$. Bu bağlamda bu hak, Avrupa İnsan Hakları Sözleşmesi madde 6(2)'de yer alan masumiyet karinesi ile ilgilidir $^{139}$. Kendi kendini suçlamama hakkı temel olarak sanığın susma hakkına saygı gösterilmesi ile ilişkilidir ${ }^{140}$.

Funke davası susma hakkının, Avrupa İnsan Hakları Mahkemesi tarafindan incelendiği ilk davadır. Başvurucu Alman vatandaşıdır ve Fransa'da yaşamaktadır. Gümrük yetkilileri, Funke'nin yurtdışındaki malvarlığının ayrıntılarını öğrenmek için evinde arama yapmışlardır. Başvurucu gerekli banka bilgilerini vermeyi reddetmiş ve bu nedenle ilgili mahkeme başvurucunun, verdiği karara uyacağı tarihe kadar geçecek her gün için başvurucuyu para cezasına çarptırmıştır. Başvurucu da Sözleşme'nin 6(1) ve (2) maddelerinin ihlâl edildiğini ileri sürmüştür. Avrupa İnsan Hakları Mahkemesi'ne göre, gümrük görevlileri kesinlikle emin olmamakla birlikte var olduğuna inandıkları belgeleri elde etmek için başvurucunun evine girmişlerdir ${ }^{141}$. SöZ konusu belgeleri elde etme konusunda yetersiz veya isteksiz olan idare, başvurucunun işlemiş olduğu iddia edilen suçların delillerini vermeye zorlama girişiminde bulunmuşlar ve bu da kişinin susma hakkını ve kendini suçlamama hakkını ihlâl etmiştir ${ }^{142}$.

\section{ç. Tanıkların Sorgulanması ve Tanık Dinlenilmesi Hakkı}

Son olarak da tanıkların sorgulanması ve tanık dinlenilmesi hakkı, âdil yargılanma hakkı kapsamında değerlendirilmiştir. Tanıkların sorgulanması

\footnotetext{
136 Saunders v. Birleşik Krallık, paragraf 68.

137 Saunders v. Birleşik Krallık, paragraf 68.

138 Saunders v. Birleşik Krallık, paragraf 68.

139 Saunders v. Birleşik Krallık, paragraf 68.

140 Saunders v. Birleşik Krallık, paragraf 69.

141 Funke v. Fransa, paragraf 44.

142 Funke v. Fransa, paragraf 44.
} 
ve tanık dinlenilmesi hakkı madde 6(3-d) kapsamında açıç̧a düzenlenmiştir. $\mathrm{Bu}$ hükme göre, bir suç ile itham edilen herkes, "İddia tanıklarını sorguya çekmek veya çektirmek, savunma tanıklarının da iddia tanıklarıyla aynı şartlar altında davet edilmelerinin ve dinlenmelerinin sağlanmasınt istemek" hakkına sahiptir ${ }^{143}$. Bu hüküm "âdil yargılanma açısından delillerin değerlendirilmesi" yönünde bir ilke ortaya koymakta ve savunma tanıklarıyla birlikte iddia tanıklarının aynı haklara sahip olduğunu ifade etmektedir ${ }^{144}$. Avrupa İnsan Hakları Mahkemesi, madde 6(3-d) hükmünü "yargılama sürecinde tarafların eşitliği ilkesinin" uzantısı olarak kabul etmektedir. Tanıkların dinlenilmesi sanığa istediği tüm kişileri tanık olarak dinletme hakkı vermemekte ve "taraflar arasinda eşitlik gözetilmek koşuluyla...sunulan bir delilin yararlı ve gerekli olup olmadiğının -6. maddenin bütününe egemen adil yargılanma kavramına uygun düştüğü ölçüde-takdirini ulusal makamlara bırakmıştır ${ }^{145}$ ". Avrupa İnsan Hakları Mahkemesi, yargılamanın hangi aşamasında olursa olsun, tanıkların sorgulanmaması ya da tanıkların dinlenilmemesinin âdil yargılanma hakkını ihlâl edeceğini kabul etmektedir ${ }^{146}$. Bu bilgiler kapsamında tanığın sorgulanması ve tanık dinletme hakkı ile ilgili olarak Chap LTD v. Ermenistan ${ }^{147}$ kararı incelenebilir. Chap LTD kararında, başvurucu bir şirket olup 2005 yllında bir yerel kanal kurmuştur. 2007 yılında yapılan vergi incelemesinde şirketin özellikle reklâm gelirlerinden vergi kaçırdığı; yani, eksik vergi beyan ettiği tespit edilmiş ve bu yönde bir rapor hazırlanmıştır. Bu rapor dikkate alınarak, şirkete eksik vergi beyanında bulunduğu için yüksek meblağda para cezası kesilmiştir. Hazırlanan rapor, Ulusal Televizyon ve Radyo Komisyonu (NTRC) başkanı tarafından verilen belgelere ve ilgili reklâmı veren iş adamlarının ifadelerine dayanmaktadır. Başvurucu şirket, ulusal düzeyde açılan davalarda NTRC başkanının ve ilgili iş adamlarının tanık olarak dinlenilmesini talep etmiş ancak bu talep reddedilmiştir. Şirket, vergi otoriteleri tarafindan hazırlanan raporun dayandırıldığ 1 tanık ifadelerinin mahkemede dinletilmediği ya da çapraz sorgu yapılması ile desteklenmediğini belirtmiştir ${ }^{148}$. Avrupa İnsan Hakları Mahke-

\footnotetext{
143 Avrupa İnsan Hakları Sözleşmesi, Avrupa Antlaşmaları Serisi, No. 5, 2010, s. 10.

144 Gözübüyük, A. Şeref/Gölcüklü, Feyyaz: Avrupa İnsan Hakları Sözleşmesi ve Uygulamas1- Avrupa İnsan Hakları Mahkemesi İnceleme ve Yargılama Yöntemi, Turhan Kitabevi, 10. Bas1, Ankara, 2013, s. 306.

145 Gözübüyük/Gölcüklü, s. 306.

146 Uzun, Mine: "Bir Adil Yargılanma Hakkı Olarak Tanı̆̆ı Sorgulama ve Tanık Dinletme Hakkının Türk Vergi Yargılamasındaki Yeri”, AÜHFD, 63(1), 2014, s. 228. App No: 15485/09 (2017).

148 Chap LTD v. Ermenistan, paragraf 45.
} 
mesi'ne göre, vergi otoriteleri başvurucu şirketin aleyhine vergi yükümlülüğü oluştururken dayandırdıkları tek delil tanık ifadeleridir ${ }^{149}$. Avrupa İnsan Hakları Mahkemesi'ne göre, tanıkların mahkemede dinlenilmemesi nedeniyle başvurucu şirketin zararlarını telafi edecek usulî güvenceler sağlanmamıştır ${ }^{150}$. Avrupa İnsan Hakları Mahkemesi, başvurucu şirketin makûl olmayan şekilde tanık dinleme hakkının kısıtlandığı sonucuna varmıştır. Başka bir ifade ile, tanıklar ne sorgulanmış ne de mahkemede dinlenilmiştir. Böylelikle de tarafların eşit düzeyde kendilerini savunma hakkının tanınmadığ sonucuna varlabilir.

\section{SONUÇ}

Devletler, vergilerin, para cezalarının ve diğer katkı paylarının ödenmesini sağlamak için düzenlemeler yapma ve gerekli tedbirler alma konusunda sinırsız bir yetkiye sahip değildirler. Bu sebeple devletler kamu yararını gerçekleştirmek, hukuka uygun olmak ve ölçülü olmak şartlarıyla mülkiyet hakkını sınırlandırabilir. Mülkiyet hakkı, vergilendirme ilişkisinde kişilerin malvarlığında bir eksilmeye neden olduğu için doğrudan mükellef haklarıyla bağlantısının olduğu söylenebilir. Vergi düzenlemeleri sırasında mükelleflerin haklarının ihlâli ile bağlantılı olarak mülkiyet hakkı ihlâl edilebilecektir. Başka bir deyişle, kişilerin mülkiyet hakkına yönelik vergiye ilişkin müdahaleler hukukî dayanağı ile kamu yararına uygun meşru bir amacı olmaması ve ölçüsüz olması durumunda, anılan müdahalelerin Avrupa İnsan Hakları Sözleşmesi'nin Ek 1 No'lu Protokol'ün 1'inci maddesinde güvence altına alınan mülkiyet hakkının ihlâlini oluşturacağını söylemek mümkündür.

Avrupa İnsan Hakları Mahkemesi kararları incelendiğinde vergi borçları, verginin fazla ödenmesi ve vergi oranlarının tespiti gibi konuların mülkiyette eksilmeye sebep olmasından dolayı mülkiyet hakkı kapsamında değerlendirildiğini görmekteyiz. Keza, Avrupa İnsan Hakları Mahkemesi kıdem tazminatını mülkiyet hakkı kapsamında ele almış olup, N.K.M. v. Macaristan kararında belirttiği gibi, vergi oranı tespitinin mükellefe şahsen aşırı bir yük getirmemesi şartıyla devletlerin bu konuda düzenleme yapabileceğini belirtmiştir.

Vergilerin konusunun, matrahının, oranının belirlenmesi gibi hususlarda yapılacak ihlâller mülkiyet hakkını doğrudan etkileyeceği için bu hak,

149 Chap LTD v. Ermenistan, paragraf 50.
150 Chap LTD v. Ermenistan, paragraf 51. 
mükellef hakları kapsamında değerlendirilmektedir. Bu hakkın mükellef hakkı kapsamında incelenmesinin sebebi vergilendirme işlemlerine dair bir hususun kişinin malvarlığında eksilme meydana getirmesidir. Böylece, mülkiyet hakkı Avrupa İnsan Hakları Sözleşmesi kapsamında Mahkeme'nin içtihatlarıyla mükellef hakkı çerçevesinde değerlendirildiği görülmektedir.

Çalışmada ele alınan bir diğer hak olan âdil yargılanmanın mümkün olabilmesi için, öncelikle mahkemeye erişim hakkının sağlanması gerekmektedir. Bu nedenle mahkemeye erişim hakkı, âdil yargılanmanın en temel unsurlarından birini oluşturmaktadır. Yargılanma imkânı olmayan bir kişinin, âdil yargılanma imkânı da olamaz. Bunun yanında, mahkemelerin bağımsız ve tarafsız olması, âdil bir yargılanmayı oluşturan bir diğer unsurdur. Adil yargılanma hakkı kapsamında olan bir diğer hak olan makûl sürede yargılanma hakkı da oldukça önemlidir. Makûl süreyi aşan bir sürede sonuçlanan vergi davaları gerek mükellefler gerekse devlet bütçesi açısından önemli zararlar ortaya çıkarmaktadır. Uzun süren dava sonucunda davayı kaybeden mükellef yüksek tutarlarda gecikme faizi ile karşı karşıya kalabilmektedir. Bu durum da mükellef hakları açısından oldukça önemlidir.

Avrupa İnsan Hakları Sözleşmesi’nin tüm yargılama süreçlerini âdil yargılanma hakkı kapsamına dâhil etmediği için bu hakkın uygulama alanının tespiti zordur. Çünkü, Sözleşme'nin 6'ncı maddesinin uygulama alanına tüm yargılama süreçleri dâhil edilmemiş olmasından kaynaklanmaktadır. $\mathrm{Bu}$ hak "medenî hak ve yükümlülükler" ve "suç isnadı" ile sınırlandırılmıştır. Böylelikle vergi davalarının medenî hak ve yükümlülükler kapsamına dahil edilip edilmeyeceği sorunu karşımıza çıkmaktadır. Bu konuda Avrupa İnsan Hakları Mahkemesi'nin verdiği Ferrazzini v. Italya kararı yol göstericidir. $\mathrm{Bu}$ kararda Avrupa İnsan Hakları Mahkemesi, vergi davalarının maddî menfaatlerle ilgili olduğunu ve bir uyuşmazlığın nitelik itibariyle maddî olması tek başına madde 6(1)'deki “medenî” kapsamında değerlendirilmesinde yeterli olmayacağını belirtmiştir. Avrupa İnsan Hakları Mahkemesi, vergi uyuşmazlıklarının madde 6(1) kapsamı dışında olduğu sonucuna varmasına rağmen, vergilendirme işlemlerinin sonucu olarak uğranılan zararın medenî hak ve yükümlülük kapsamında değerlendirilebileceğini belirtmiştir. Avrupa İnsan Hakları Mahkemesi, ilk kez Bendenoun v. Fransa kararında vergi cezalarının, suç isnadı olduğunu kabul etmiştir.

Sonuç olarak, Avrupa İnsan Hakları Mahkemesi'nin kararları, millî yargı organları üzerinde önemli bir etkiye sahiptir. Mükellef hakları konusunda değişen dünya anlayışının hukukî meseleler üzerindeki etkileri, verilen kararlar incelendiğinde görülmektedir. Devletler, hukuka aykırı bir vergi- 
lendirme işlemi gerçekleştirdiği takdirde mükellefe verdiği zararı tazmin etmek durumundadır. Avrupa İnsan Hakları Sözleşmesi'nde açıkça mükellef hakları kavramına yer verilmemiştir ve Mahkeme de kararlarında açıkça mükellef haklarından bahsetmemiştir. Ancak, Mahkeme'nin vergi uyuşmazlıklarına ilişkin kararlarına baktığımızda, mülkiyet hakkı ve âdil yargılanma hakkının mükellef hakları ile yakın ilişki içerisinde olduğu görülmektedir. Böylece mükellef haklarının uluslararası düzeyde korunmasının, Avrupa İnsan Hakları Mahkemesi tarafından sağlandığı sonucuna varılabilir. 


\section{KAYNAKÇA}

Acu, Melek: "Bireysel Başvuruya Konu Edilebilecek Haklar", (Türkiye Barolar Birliği Dergisi, (110), 2014, ss. 403-434).

Akça, Kürşat: "Anayasa Mahkemesi Kararlarında Mülkiyet Hakkı”, (İnönü Üniversitesi Hukuk Fakültesi Dergisi, 1, 2015, ss. 543-596).

Akıllıoğlu, Tekin: “Avrupa İnsan Hakları Mahkemesi Kararlarında Mülkiyet Hakkı ve Kazanılmış Hak Üzerine Bazı Gözlemler”, (İdare Hukuku ve İlimleri Dergisi, 15(2), 2012, ss. 9-27).

Arslan Öncü, Gülay: "Vergi Hukuku ve Yargılamasına Avrupa İnsan Hakları Sözleşmesinin Uygulanabilirliği: Avrupa İnsan Hakları Kararları Işı̆̆ında Bir Analiz”, (Türkiye Adalet Akademisi Dergisi, 6(20), 2015, ss. 139-190).

Avrupa İnsan Hakları Sözleşmesi, Avrupa Antlaşmaları Serisi, No. 5, 2010.

Aydın, Alper: "Mahkemeye Erişim Hakkı Işı̆̆ında Vergi Mahkemelerinde Dava Açma Süreleri”, (Türkiye Adalet Akademisi Dergisi, (34), 2018, ss. 537-585).

Baker, Philip: "Taxation and the European Convention on Human Rights", British Tax Review, 2000, http://www.fieldtax.com/wp-content/ uploads/2015/04/BTR-2000-4-211-377-Taxation-and-the-EuropeanConvention-on-Human-Rights.pdf, E. T.: 12.04.2019.

Başaran, Başar: Adil Yargılanma Hakk1, (Ankara Üniversitesi, Sosyal Bilimler Enstitüsü, Kamu Hukuku Anabilim Dalı, Yüksek Lisans Tezi), Ankara, 2007.

Bayraktar, Tuğba/Koyuncu, Nuran: "Adil Yargılanma Hakkı", 2nd International Congress on Political, Economic and Social Studies (ICPESS), 2017, ss. 161-177.

Cebre, Ayvaz: "Hak Arama Yolları ve Adil Yargılanma Hakkı", (Türkiye Adalet Akademisi Dergisi, 1(5), 2011, ss. 373-396).

Centel, Nur: "Adil Yargılama İlkesi ve Türk Hukukundaki Bazı Sorunlar", (Marmara Üniversitesi Hukuk Fakültesi Hukuk Araştırmaları Dergisi, 16(1-2), 2010, ss. 3-14).

Çağıran, Mehmet Emin: Uluslararası Alanda İnsan Hakları, Genişletilmiş Gözden Geçirilmiş 4. Bask1, (Turhan Kitabevi), Ankara, 2020.

Çayan, Gökhan: Adil Yargılanma Hakkı, Birinci Basım, (Legal Yayıncılık), İstanbul, 2016, (Adil Yargilanma). 
Çayan, Gökhan: “Avrupa İnsan Hakları Mahkemesi ve Anayasa Mahkemesi Kararları Işığında Mahkemeye Erişim Hakkı", (Türkiye Adalet Akademisi Dergisi, (28), 2016, ss. 235-271), (Avrupa İnsan Hakları).

Çırak, Ezgi: “Avrupa İnsan Hakları Sözleşmesi Çerçevesinde Adil Yargılanma Hakkının Uygulama Alanı”, (Dokuz Eylül Üniversitesi Hukuk Fakültesi Dergisi, Prof. Dr. Durmuş Tezcan'a Armağan, 21, 2019, ss. 997-1028).

Değirmencioğlu, Burcu: “Avrupa İnsan Hakları Mahkemesi İçtihatları Işığında "Masumiyet Karinesi"nin Korunması", (Ankara Sosyal Bilimler Üniversitesi Hukuk Fakültesi Dergisi, (2), 2019, ss. 307-356).

Demirbaş, Timur: "Soruşturma Evresinde Şüphelinin İfadesi Alınması ve Müdafilik”, (Legal Hukuk Dergisi, (32), 2005, ss. 2871-2883).

Demirkıran, Eyüp Kaan: “İnsan Hakları Avrupa Sözleşmesi ve 1982 Anayasası Bağlamında Etkili Başvuru Hakkı ve Adil Yargılanma Hakkının Kapsam Alanlarının Karşılaştırılması", (Türk-Alman Üniversitesi Hukuk Fakültesi Dergisi, 2(1), 2020, ss. 49-88).

Dilemre Öden, Begüm: Avrupa İnsan Hakları Mahkemesi Kararlarının Türk Vergi Hukukuna Etkisi, 1. Bask1, (Savaş Yayınevi), Ankara, 2017, (Türk Vergi Hukukuna Etkisi).

Dilemre Öden, Begüm: "Vergi Mükelleflerinin Mahkemeye Erişim Hakkı", (Vergi Sorunları Dergisi, (372), 2019, ss. 122-131), (Mahkemeye Erişim Hakk1).

Dinç, Güney: “Avrupa İnsan Hakları Sözleşmesi ve Mülkiyet Hakkı”, (Türkiye Barolar Birliği Dergisi, (51), 2004, ss. 133-151).

Doğmuş, Simay: "Vergi Uyuşmazlıkları Bakımından Makul Sürede Yargılanma Hakkı", (Çankaya Üniversitesi Hukuk Fakültesi Dergisi, 5(1), 2020, ss. 1149-1190).

Doğru, Osman/Nalbant, Atilla: İnsan Hakları Avrupa Sözleşmesi Açıklama ve Önemli Kararlar, Cilt 1, 2. Baskı, (Yargıtay Başkanlığı ve Avrupa Konseyi Ortak Yayını), Ankara, 2013.

Ekinci, Ahmet: "Anayasa Mahkemesi'nin Bireysel Başvuru Kararlarında Mahkemeye Erişim Hakkı", (Gazi Üniversitesi Hukuk Fakültesi Dergisi, 18(3-4), 2014, ss. 821-848).

Er, Selami: "Mükellef Hakları ve Kamuda Faiz Uygulamaları", (Sayıştay Dergisi, (81), 2011, ss. 3-32).

Ertutar, Ege: "Vergi Uyuşmazlıkları Kapsamında Mülkiyet Hakkının Avrupa İnsan Hakları Mahkemesi Nezdinde Değerlendirilmesi", 
http://www.ksavukatlik.com/vergi-uyusmazliklari-kapsamindamulkiyet-hakkinin-avrupa-insan-haklari-mahkemesi-nezdindedegerlendirilmesi/, E.T.: 18.08.2020.

Gemalmaz, Haydar Burak: "Avrupa İnsan Hakları Sözleşmesi Açısından Mülkiyet Hakkının Sinırlanmasında 'Adil Denge' İlkesi”, (İstanbul Üniversitesi Hukuk Fakültesi Mecmuas1, 69(1-2), 2011, ss. 649-674), (Adil Denge İlkesi).

Gemalmaz, Haydar Burak: "Mali Güç Ölçütünü Dikkate Almayan Aşırı Vergi Mülkiyet Hakkı İhlalidir: Avrupa İnsan Hakları Mahkemesi'nin Macaristan'a Karşı 14 Mayıs 2013 Tarihinde Verdiği N.K.M. Kararının İncelenmesi", (İstanbul Barosu Dergisi, 88(2), 2014, ss. 128-143), (N.K.M. Kararı).

Gölcüklü, Feyyaz: “Avrupa İnsan Hakları Sözleşmesinde Kişi Özgürlüğü ve Güvenliği”, (Ankara Üniversitesi Siyasal Bilgiler Fakültesi Dergisi, 49(3), 1994, ss. 199-218).

Gözler, Kemal: Anayasa Hukukuna Giriş, 18. Baskıdan Ek Baskı, (Ekin Yayınevi), Bursa, 2012.

Gözübüyük, A. Şeref/Gölcüklü, Feyyaz: Avrupa İnsan Hakları Sözleşmesi ve Uygulamas1- Avrupa İnsan Hakları Mahkemesi İnceleme ve Yargılama Yöntemi, 10. Bası, (Turhan Kitabevi), Ankara, 2013.

Grgić, Aida/Mataga, Zvonimir/Longar, Matija/Vilfan, Ana: Avrupa İnsan Hakları Sözleşmesi Kapsamında Mülkiyet Hakkı Avrupa İnsan Hakları Sözleşmesi ve Ek Protokollerinin Uygulanmasına İlişkin Kılavuz Kitap, Avrupa Konseyi İnsan Hakları El Kitapları, (Çeviren: Özgür Heval Çinar ve Abdulcelil Kaya), Numara 10, Haziran, Belçika, 2007.

Güngör, Burak: Silahların Eşitliği İlkesi ve Çelişmeli Yargılama Hakkı'nın Bireysel Başvuru Usulünde İncelenmesi, (Kocaeli Üniversitesi, Sosyal Bilimler Enstitüsü, Kamu Hukuku Anabilim Dalı, Doktora Tezi), Kocaeli, 2019.

Haydar, Nuran: Susma Hakkı, (Seçkin Yayıncılık), Ankara, 2019.

Hoşten, Zamira: "Anayasa Mahkemesi ve AİHM Kararları Çerçevesinde Adil Yargilanma Hakkı", (Terazi Hukuk Dergisi, 14(156), 2019, ss. 1544-1551).

Işık, Hüseyin: "Suçsuzluk Karinesi”, (Uyuşmazlık Mahkemesi Dergisi, (1), 2012, ss. 103-145). 
İnce Tunçer, Asuman: "Susma Hakkı Bağlamında Birtakım Ceza Muhakemesi İşlemlerinin Değerlendirilmesi”, (Anadolu Üniversitesi Hukuk Fakültesi Dergisi, 4(2), 2018, ss. 355-379).

Kamışlı, Gani: Avrupa İnsan Hakları Mahkemesi ve Anayasa Mahkemesi Kararları Işı̆ğında Mülkiyet Uyuşmazlıkları, Güncellenmiş ve Genişletilmiş 2. Bask1, (Seçkin Yayıncılık), Ankara, 2018.

Kan Aydın, Çağrı: “Adil Yargılanmanın Bir Unsuru Olarak Susma Hakkı", (Türkiye Barolar Birliği Dergisi, (91), 2010, ss. 146-180).

Karakoç, Yusuf: Genel Vergi Hukuku, Gözden Geçirilmiş ve Genişletilmiş 7. Bas1, (Yetkin Yayınları), Ankara, 2014, (Genel Vergi).

Karakoç, Yusuf: Vergi Yargılaması Hukuku-Vergi Anlaşmazlıklarının/ Uyuşmazlıklarının Çözüm Yolları, Gözden Geçirilmiş ve Genişletilmiş 4. Bask1, (Yetkin Yayınları), Ankara, 2017, (Vergi Yargilaması).

Karataş, Mustafa: "Anayasa Mahkemesi ve AİHM Kararları Işı̆̆ında Vergilendirme Yoluyla Mülkiyet Hakkına Müdahalenin Sinırları", (IX. Genç Vergi Hukukçuları Sempozyumu, 2019, ss. 163-194).

Kartal, Kaya: "Adil Yargılanma Hakkı", (Genç Hukukçular Hukuk Okumalar1, 2009, ss. 45-63).

Kaşıkara, M. Serhat: “Avrupa İnsan Hakları Sözleşmesi’nin 6. Maddesi Çerçevesinde Makul Süre İçerisinde Yargılanma Hakkı", (Türkiye Barolar Birliği Dergisi, (84), 2009, ss. 231-259).

Keskin, Bayram: "İdari Yargılamada Makul Süre Kavramının Avrupa İnsan Hakları Mahkemesi Kararları Ișı̆̆ında İncelenmesi”, (İnönü Üniversitesi Hukuk Fakültesi Dergisi, 9(2), 2018, ss. 391-414).

Kocaoğlu, Serhat Sinan: "Susma Hakkı", (Ankara Barosu Dergisi, (1), 2011, ss. 29-58).

Kup Belge, Kamuran: İdari Yargı Yönüyle Adil Yargılanma Hakk1, (Ondokuz Mayıs Üniversitesi, Sosyal Bilimler Enstitüsü, Kamu Hukuku Anabilim Dalı, Yüksek Lisans Tezi), Samsun, 2019.

Odabaş Sağır, Esin: Avrupa İnsan Hakları Sözleşmesi Çerçevesinde Gerçek Kişilerin Mülkiyet Hakkı, (Beykent Üniversitesi, Sosyal Bilimler Enstitüsü, Hukuk Anabilim Dalı, Yüksek Lisans Tezi), İstanbul, 2016.

Oğuzman, Kemal/Barlas, Nami: Medeni Hukuk Giriş Kaynaklar Temel Kavramlar, 13. Bası, (Arıkan Basım Yayım), Denizli, 2006. 
Ormanoğlu, Hatice Derya: “Anayasal Bağlamda ve Avrupa İnsan Hakları Sözleşmesi Boyutuyla Suçsuzluk Karinesi”, (Ankara Üniversitesi Hukuk Fakültesi Dergisi, 65(4), 2016, ss. 2241-2276).

Özgüven, Ali Volkan: “Adil Yargılanma İlkesi ve Vergi İhtilaflarındaki Uygulamas1-I", (Vergi Sorunlar1 Dergisi, (197), 2005, ss. 189-206).

Özkan Duvan, Ayşe: "Bireysel Başvuru Kararlarında Makul Sürede Yargılanma Hakkı", (Ankara Üniversitesi Hukuk Fakültesi Dergisi, 68(1), 2019, ss. 287-336).

Pekcanıtez, Hakan: "Medeni Yargıda Adil Yargılama", (İzmir Barosu Dergisi, (2), 1997, ss. 35-55).

Perdecioğlu, İsmail Emrah: Mülkiyet Hakk1 Yönünden Devletin Pozitif Yükümlülükleri, Birinci Baskı, Adalet Yayınevi, Ankara, 2020.

Sarıcaoğlu, Ercan: "AİHM'in Vergilerin Kanuniliğinde Öngörülebilirlik İlkesine Bakışı, Avrupa İnsan Hakları Mahkemesi 5. Daire SerkovUkrayna Davası (Başvuru No: 39766/05)", (Küresel Bakış, 1(3), 2011, ss. 131-144).

Sencer, Rasih Feridun: "Adil Yargilanma Hakk1”, (İzmir Barosu Dergisi, 2013, ss. 108-173).

Sevdiren, Öznur: "Çelişmeli Yargılama ve Silahların Eşitliği İlkeleri Bağlamında Teşhis İşlemi ve Bu İşlemde Müdafiin Hazır Bulunma Yetkisi”, (Galatasaray Üniversitesi Hukuk Fakültesi Dergisi, (1), 2019, ss. 15-55).

Şahin, İsmail: "Anayasa Mahkemesi Kararlarında Makul Sürede Yargılanma Hakkının İhlali”, (Yıldırım Beyzıt Hukuk Dergisi, (1), 2019, ss. 223-255), (Anayasa Mahkemesi Kararlarında).

Şahin, Kemal: “Avrupa İnsan Hakları Sözleşmesi Hukukunda, Doğal Afetlerde Yaşam Hakkı ve Mülkiyet Hakkı Bağlamında Devletin Sorumluluğu: Budayeva Kararı", (Marmara Üniversitesi Hukuk Fakültesi Hukuk Araştırmaları Dergisi, 19(3), 2013, ss. 53-146), (Doğal Afetlerde).

Şimşek, Suat: "Vergi Politikaları, Mülkiyet Hakkı ve Avrupa İnsan Hakları Mahkemesi", (Maliye Dergisi), 159 (Temmuz-Aralık), 2010, ss. 323345), (Vergi Politikaları).

Şimşek, Suat: Türk Hukukunda ve Avrupa İnsan Hakları Sözleşmesinde Mülkiyet Hakkı, Hermes Matbaacılık, (T.C. Maliye Bakanlığı Strateji Geliştirme Başkanlığı, Yayın No: 2011/413), Ankara, 2011, (Mülkiyet Hakk1). 
Tabak, Bahadırhan: Mülkiyet Hakkı ve Anayasa Mahkemesinin Mülkiyet Hakkına Bakışı, (Çankaya Üniversitesi, Sosyal Bilimler Enstitüsü, Kamu Hukuku Anabilim Dalı, Yüksek Lisans Tezi), Ankara, 2016.

Taner, Fahri Gökçen: Ceza Muhakemesi Hukukunda Adil Yargılanma Hakkı Bağlamında Çelişme ve Silahların Eşitliği, Birinci Baskı, (Seçkin Yayıncılık), Ankara, 2019.

Tezcan, Durmuş: “AİHM'in Silahların Eşitliği Kapsamında, Göç-Türkiye Davasıyla Başlayan Sürece Nihat Ateş-Türkiye Davasıyla Getirdiği Yeni Anlayış”, (Yakın Doğu Üniversitesi Hukuk Fakültesi Dergisi, Prof. Dr. Yıldırım Uler'e Armağan, 2014, ss. 525-532).

Tezcan, Durmuş/Erdem, Mustafa Ruhan/Sancakdar, Oğuz/Önok, R. Murat: İnsan Hakları El Kitabı, Genişletilmiş 5. Baskı, (Seçkin Yayınc1lık), Ankara, 2014.

Turan, Hüseyin: "Avrupa İnsan Hakları Mahkemesi İçtihatlarında Makul Sürede Yargilanma Hakkı", (Türkiye Adalet Akademisi Dergisi, (11), 2012, ss. 47-75).

Turinay, Faruk: “Avrupa İnsan Hakları Mahkemesi'nin 1996 Tarihli Miailhe V. Fransa Kararı Üzerine Bir İnceleme”, (Ankara Barosu Dergisi, (3), 2014, ss. 333-346).

Uçan, Emine Sevcan: Avrupa İnsan Hakları Sözleşmesi Çerçevesinde Türk Vergi Yargılaması Hukukunda Adil Yargılanma Hakkı, (Dokuz Eylül Üniversitesi, Sosyal Bilimler Enstitüsü, Kamu Hukuku Anabilim Dalı, Yüksek Lisans Tezi), İzmir, 2013.

Uzun, Mine: "Bir Adil Yargılanma Hakkı Olarak Tanığı Sorgulama ve Tanık Dinletme Hakkının Türk Vergi Yargılamasındaki Yeri", (AÜHFD, 63(1), 2014, ss. 219-245).

Vitkauskas, Dovydas/Dikov, Grigoriy: Avrupa İnsan Hakları Sözleşmesi Kapsamında Adil Yargılama Hakkının Korunması, (Avrupa Konseyi İnsan Hakları El Kitapları), (Çeviren: Serkan Cengiz), Strazburg, 2012.

Yaltı, Billur: Vergi Yükümlüsünün Hakları, 1. Bası, (Beta Basım Yayım Dağıtım), İstanbul, 2006.

Yücel, Özge: “Avrupa İnsan Hakları Sözleşmesi’ne Göre Kamulaştırmasız El Atma”, (Prof. Dr. Tunçer Karamustafaoğlu'na Armağan), Adalet Yayınevi, Ankara, 2010, http://www.turkhukuksitesi.com/makale_ 1281.htm, E.T.: 04.04.2019. 


\section{Avrupa İnsan Hakları Mahkemesi Kararları}

A.P., M.P. ve T.P. v. İsviçre App No: 71/1996/690/882 (1997).

Barbera, Messegue ve Jabardo v. İspanya App No: 10590/83 (1988).

Bendenoun v. Fransa App No: 12547/86 (1994).

Bulves v. Bulgaristan App No: 3991/03 (2009).

Chap LTD v. Ermenistan App No: 15485/09 (2017).

Eko-Elda AVEE v. Yunanistan App No: 10162/02 (2006).

Ferrazzini v. İtalya App No: $44759 / 98$ (2001).

Funke v. Fransa App No: 10828/84 (1993).

Gasus Dosier und Fördertechnik GmbH v. Hollanda App No: 15375/89 (1995).

Golder v. Birleşik Krallık App No: $4451 / 70$ (1975).

Hentrich v. Fransa App No: 13616/88 (1994).

Hozee v. Hollanda App No: 81/1997/865/1076 (1998).

Janosevic v. İsveç App No: $34619 / 97$ (2002).

J.B. v. İsviçre App No: $31827 / 96$ (2001).

JJ v. Hollanda App No: 21351/93 (1998).

John Murray v. Birleşik Krallık App No: 18731/91 (1996).

König v. Almanya App No: 6232/73 (1978).

Kress v. Fransa App No: 39594/98 (2001).

N.K.M. v. Macaristan App No: 66529/11 (2013).

Ringeisen v. Avusturya App No: 2614/65 (1973).

Saunders v. Birleşik Krallık App No: $19187 / 91$ (1996).

S.A. Dangeville v. Fransa App No: $36677 / 97$ (2002).

Serkov v. Ukrayna App No: 39766/05 (2011).

Sporrong ve Lönnroth v. İsveç App No: 7151/75; $7152 / 75$ (1982).

Vastberga Taxi Aktiebolag ve Vulic v. İsveç App No: 36985/97 (2002). 